Review

\title{
Advances in the Diagnosis and Treatment of Pediatric Acute Lymphoblastic Leukemia
}

\author{
Hiroto Inaba ${ }^{1,2, *}$ and Ching-Hon Pui ${ }^{1,2}$ \\ 1 Department of Oncology, St. Jude Children's Research Hospital, Memphis, TN 38105, USA; \\ ching-hon.pui@stjude.org \\ 2 Department of Pediatrics, University of Tennessee Health Science Center, Memphis, TN 38163, USA \\ * Correspondence: hiroto.inaba@stjude.org; Tel.: +1-901-595-3300; Fax: +1-901-521-9005
}

Citation: Inaba, H.; Pui, C.-H. Advances in the Diagnosis and Treatment of Pediatric Acute Lymphoblastic Leukemia. J. Clin. Med. 2021, 10, 1926. https:// doi.org/10.3390/jcm10091926

Academic Editor: Tadeusz Robak

Received: 31 March 2021

Accepted: 25 April 2021

Published: 29 April 2021

Publisher's Note: MDPI stays neutral with regard to jurisdictional claims in published maps and institutional affiliations.

Copyright: (c) 2021 by the authors. Licensee MDPI, Basel, Switzerland. This article is an open access article distributed under the terms and conditions of the Creative Commons Attribution (CC BY) license (https:/ / creativecommons.org/licenses/by/ $4.0 /)$.

\begin{abstract}
The outcomes of pediatric acute lymphoblastic leukemia (ALL) have improved remarkably during the last five decades. Such improvements were made possible by the incorporation of new diagnostic technologies, the effective administration of conventional chemotherapeutic agents, and the provision of better supportive care. With the 5 -year survival rates now exceeding $90 \%$ in highincome countries, the goal for the next decade is to improve survival further toward $100 \%$ and to minimize treatment-related adverse effects. Based on genome-wide analyses, especially RNAsequencing analyses, ALL can be classified into more than 20 B-lineage subtypes and more than 10 T-lineage subtypes with prognostic and therapeutic implications. Response to treatment is another critical prognostic factor, and detailed analysis of minimal residual disease can detect levels as low as one ALL cell among 1 million total cells. Such detailed analysis can facilitate the rational use of molecular targeted therapy and immunotherapy, which have emerged as new treatment strategies that can replace or reduce the use of conventional chemotherapy.
\end{abstract}

Keywords: acute lymphoblastic leukemia; pediatric; advances; diagnosis; treatment

\section{Introduction}

Approximately 6000 new cases of acute lymphoblastic leukemia (ALL) are diagnosed in the United States annually [1-4]. ALL is the most common pediatric cancer (representing approximately $25 \%$ of cancer diagnoses), and approximately $60 \%$ of all cases occur in children and adolescents younger than 20 years, with an annual incidence of 36.2 per 1 million persons and a peak age of incidence of two to five years (at which there are $>90$ cases per 1 million persons) [5]. ALL is diagnosed more frequently in boys than in girls, with a ratio of approximately 1.3:1. The annual incidence of ALL differs markedly according to race and ethnic group; there are 40.9 cases per million in the Hispanic population, 35.6 cases per million in the white population, and 14.8 cases per million in the black population [6]. ALL cases are broadly classified as B-ALL or T-ALL based on immunophenotyping, with B-ALL comprising approximately $85 \%$ of cases, although this percentage can differ depending on age at diagnosis, race, or ethnicity.

Currently, the survival of pediatric patients with ALL treated in high-income countries exceeds $90 \%$ (Figure 1) [1-4]. Chemotherapy is given in four important phases: remission induction, consolidation, reinduction (delayed intensification), and continuation (maintenance). Chemotherapy is administered based on stratified risk classification, as determined by clinical factors (e.g., age (1-9.9 years vs. $<1$ or $\geq 10$ years) and white blood cell (WBC) counts $\left(<50 \times 10^{9} / \mathrm{L}\right.$ vs. $\left.\geq 50 \times 10^{9} / \mathrm{L}\right)$ at diagnosis), cytogenetic and genomic analysis of ALL cells, and response evaluation with a minimal residual disease (MRD) assay. Dosage adjustment based on pharmacodynamic and pharmacogenomic studies and supportive care (e.g., prevention and treatment of infection) have also contributed substantially to improved outcomes. Therefore, current dosages/schedules for "conventional" chemotherapy have been truly optimized. 


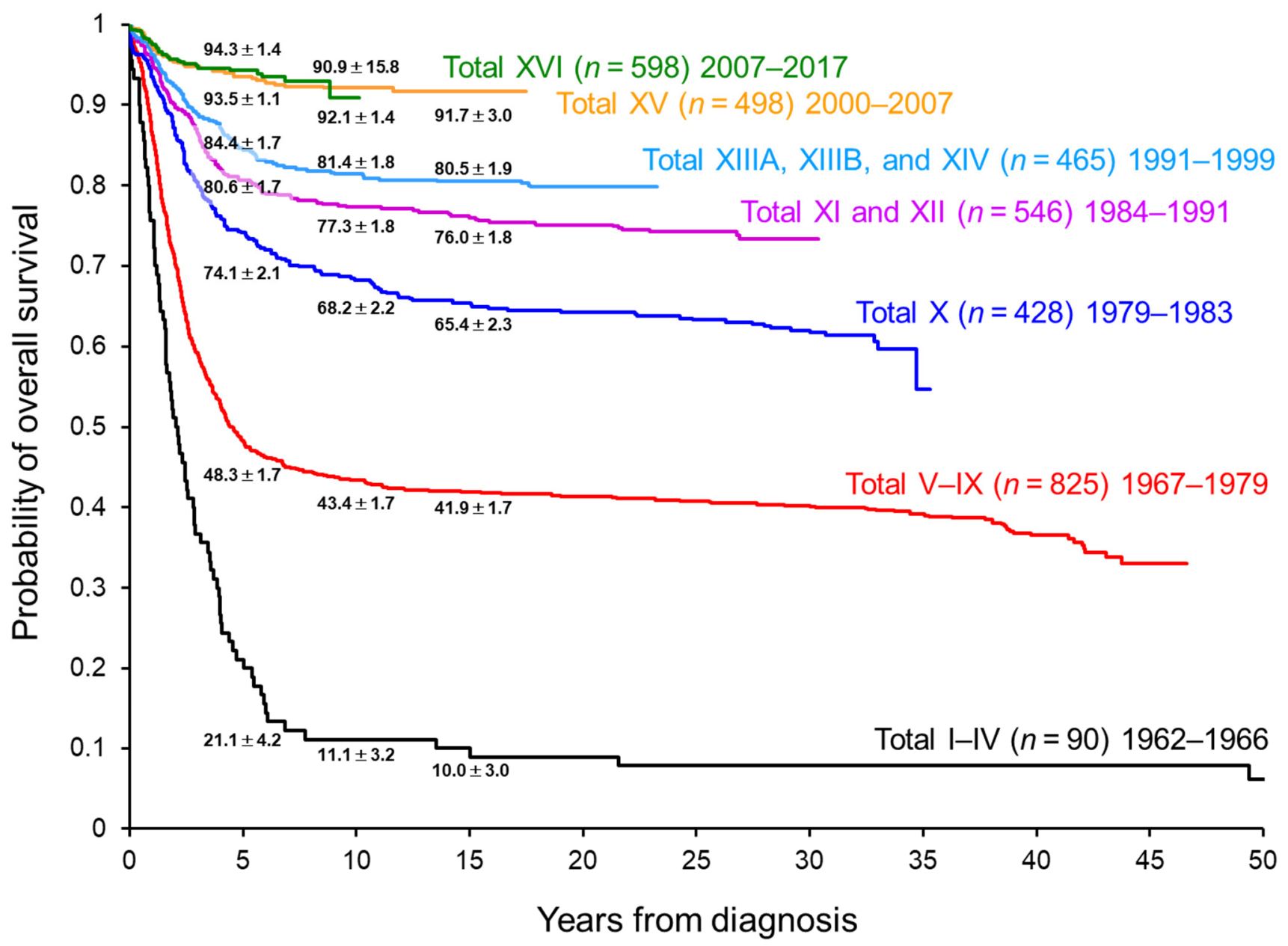

Figure 1. Overall survival of pediatric patients with acute lymphoblastic leukemia treated in the St. Jude Total Therapy studies.

With the current high rate of survival, further improvement in outcomes with conventional chemotherapy is challenging. In fact, there was very little improvement in 5-year overall survival (OS) between our two recent frontline ALL trials, St. Jude Total Therapy XV (5-year OS: 93.5\%) and XVI (5-year OS: 94.3\%) (Figure 1) [7,8]. Most of the conventional chemotherapy agents were approved by the US Food and Drug Administration before 1980 (Table 1), and their therapeutic intensity has been pushed to the limit of tolerance. Accordingly, further intensification of conventional chemotherapy could lead to only minimal improvement in overall outcomes while increasing adverse effects.

Recently, several molecular targeted agents and immunotherapy approaches have been introduced, and they promise to improve outcomes. For these agents to be used optimally, detailed genetic characterization of leukemia cells and response evaluation by MRD in individual patients are critical. In this review, we will review the genetic subgroups of ALL, the evaluation of MRD, and newer treatment strategies. 
Table 1. Representative medications used in the treatment of patients with acute lymphoblastic leukemia and the year of US Food and Drug Administration approval.

\begin{tabular}{|c|c|}
\hline Drugs & Year Approved in the US * \\
\hline \multicolumn{2}{|c|}{ Conventional chemotherapy } \\
\hline Mercaptopurine & 1953 \\
\hline Methotrexate & 1953 \\
\hline Prednisone & 1955 \\
\hline Dexamethasone & 1958 \\
\hline Cyclophosphamide & 1959 \\
\hline Vincristine & 1963 \\
\hline Thioguanine & 1966 \\
\hline Cytarabine & 1969 \\
\hline Doxorubicin & 1974 \\
\hline L-Asparaginase & 1978 \\
\hline Daunorubicin & 1979 \\
\hline \multicolumn{2}{|l|}{ New formulations or agents } \\
\hline Pegaspargase & 1994 \\
\hline Nelarabine & 2005 \\
\hline Erwinase & 2011 \\
\hline Vincristine sulfate liposome injection & 2012 \\
\hline Calaspargase & 2018 \\
\hline \multicolumn{2}{|c|}{ Molecular targeted therapy } \\
\hline \multicolumn{2}{|l|}{ ABL1 inhibitors } \\
\hline Imatinib & 2001 \\
\hline Dasatinib & 2006 \\
\hline Nilotinib & 2007 \\
\hline Ponatinib & 2012 \\
\hline \multicolumn{2}{|l|}{ JAK inhibitor } \\
\hline Ruxolitinib & 2011 \\
\hline \multicolumn{2}{|l|}{$B C L-2$ and $B C L-X_{L}$ inhibitors } \\
\hline Venotoclax & 2016 \\
\hline Navitoclax & NA \\
\hline \multicolumn{2}{|l|}{ Proteasome inhibitors } \\
\hline Bortezomib & 2003 \\
\hline Carfilzomib & 2012 \\
\hline Ixazomib & 2015 \\
\hline \multicolumn{2}{|l|}{ mTOR inhibitors } \\
\hline Sirolimus & 1999 \\
\hline Temsirolimus & 2007 \\
\hline Everolimus & 2009 \\
\hline \multicolumn{2}{|l|}{ DNA methyltransferase inhibitors } \\
\hline Azacitidine & 2004 \\
\hline Decitabine & 2006 \\
\hline \multicolumn{2}{|l|}{ Histone deacetylase inhibitors } \\
\hline Vorinostat & 2006 \\
\hline Panobinostat & 2015 \\
\hline \multicolumn{2}{|l|}{ Bromodomain inhibitor } \\
\hline JQ1 & NA \\
\hline \multicolumn{2}{|l|}{ DOT1 inhibitor } \\
\hline Pinometostat & NA \\
\hline \multicolumn{2}{|l|}{ Menin inhibitor } \\
\hline SNDX-5613 & NA \\
\hline
\end{tabular}


Table 1. Cont.

\begin{tabular}{cc}
\hline \multicolumn{1}{c}{ Drugs } & Year Approved in the US * \\
\hline \multicolumn{1}{c}{ Immunotherapy } & \\
\hline $\begin{array}{c}\text { Unconjugated antibodies } \\
\text { Rituximab (CD20) }\end{array}$ & 1997 \\
Ofatumumab (CD20) & 2009 \\
Epratuzumab (CD22) & $\mathrm{NA}$ \\
Daratumumab (CD38) & 2015 \\
Alemtuzumab (CD52) & 2001 \\
\hline Bispecific antibody & \\
Blinatumomab (CD19) & 2014 \\
\hline Chimeric antigen receptor (CAR) T cells & 2017 \\
Tisagenlecleucel (CD19) & 2017 \\
\hline Antibody-drug conjugate & \\
Inotuzumab ozogamicin (CD22) & \\
\hline * Approval by the US Food and Drug Administration is not limited to indications for pediatric acute lymphoblastic \\
leukemia. Abbreviation: NA, not approved.
\end{tabular}

\section{Genetic Characterization of Acute Lymphoblastic Leukemia}

The revolutionized approach to genomic analysis subdivides pediatric ALL into more than 30 genetic subgroups [9-11]. In B-ALL, recurrent genomic subtypes are characterized by chromosomal aneuploidy, i.e., hyperdiploidy ( $>50$ chromosomes) or hypodiploidy (<44 chromosomes), and by rearrangements: ETV6/RUNX1 fusion, TCF3/PBX1 fusion, $B C R / A B L 1$ fusion, and KMT2A (MLL) rearrangement (Figure 2 and Table 2). Genetic abnormalities newly identified by comprehensive genomic analyses include $B C R / A B L 1-$ like ALL (Ph-like ALL), intrachromosomal amplification of chromosome 21 (iAMP21), DUX4-rearranged ALL, ZNF384-rearranged ALL, MEF2D-rearranged ALL, PAX5-altered (PAX5alt) ALL, NUTM1-rearranged ALL, and ETV6/RUNX1-like ALL. Characterization of genetic abnormalities in ALL cells is important in order to identify unfavorable genetic abnormalities and to incorporate molecular targeted therapy to reduce the risk of relapse.

Table 2. Genetic subtypes and treatment approach.

\begin{tabular}{ccc}
\hline Category & Characteristics & Therapeutic Approach \\
\hline & B-lymphoblastic leukemia & \\
\hline LTV6-risk genetics & Reduction of intensity, MRD based \\
\hline Hyperdiploidy & Excellent prognosis & Reduction of intensity, MRD based \\
\hline DUX4-rearranged & $\begin{array}{c}\text { Most have focal ERG deletions and } \\
\text { favorable outcome despite } \\
\text { IKZF1 alterations }\end{array}$ & Standard dose intensity, MRD based \\
\hline TCF3/PBX1 & Intermediate-risk genetics & intensive intrathecal therapy \\
\hline PAX5alt & Higher incidence in African Americans, \\
cytoplasmic $\mu$-chain & Standard dose intensity, MRD based, \\
PAX5 p.Pro80Arg & PAX5 fusions, mutation, or amplifications & Standard dose intensity, MRD based \\
\hline ZNF384-rearranged & Frequent signaling pathway alterations & $\begin{array}{c}\text { Standard dose intensity, MRD based, } \\
\text { JAK inhibitors }\end{array}$ \\
\hline
\end{tabular}


Table 2. Cont.

\begin{tabular}{|c|c|c|}
\hline Category & Characteristics & Therapeutic Approach \\
\hline \multicolumn{3}{|c|}{ B-lymphoblastic leukemia } \\
\hline iAMP21 & $\begin{array}{c}\text { Additional copies of chromosome 21, } \\
\text { worse outcome with } \\
\text { low-intensity therapy }\end{array}$ & Intensification of therapy \\
\hline NUTM1-rearranged * & $\begin{array}{l}\text { Rare; more common in infants, } \\
\text { excellent prognosis }\end{array}$ & Standard dose intensity, MRD based \\
\hline \multicolumn{3}{|c|}{ High-risk genetics } \\
\hline Near-haploid & $\begin{array}{l}\text { 24-31 chromosomes, Ras-activating } \\
\text { mutations, inactivation of } I K Z F 3\end{array}$ & $\begin{array}{l}\text { Intensification of therapy, MRD based, } \\
\text { BCL-2 inhibitors }\end{array}$ \\
\hline Low-hypodiploid & $\begin{array}{l}\text { 32-39 chromosomes, TP53 mutations } \\
\text { (somatic and germline) }\end{array}$ & $\begin{array}{l}\text { Intensification of therapy, MRD based, } \\
\text { BCL-2 inhibitors }\end{array}$ \\
\hline$B C R / A B L 1$ & $\begin{array}{l}\text { Prognosis improved with ABL1 } \\
\text { inhibitors, common deletions of } I K Z F 1\end{array}$ & ABL1 inhibitors, BCL-2 inhibitors \\
\hline $\begin{array}{l}B C R / A B L 1 \text {-like; JAK-STAT } \\
\text { activating mutation }\end{array}$ & $\begin{array}{c}\text { CRLF2 rearranged }(I G H-C R L F 2, \\
P 2 R Y 8-C R L F 2), J A K 1 / 2, E P O R, I L 7 R, \\
\text { SH2B3 mutation }\end{array}$ & JAK inhibitors, BCL-2 inhibitors \\
\hline$B C R / A B L 1$-like; $A B L 1$-class & $\begin{array}{l}\text { Kinase-activating lesions, potentially } \\
\text { amenable to kinase inhibition }\end{array}$ & ABL1 inhibitors, BCL-2 inhibitors \\
\hline KMT2A $(M L L)$-rearranged & $\begin{array}{l}\text { Common in infant ALL, few } \\
\text { cooperating mutations }\end{array}$ & $\begin{array}{l}\text { DOT1L inhibitors, menin inhibitors, } \\
\text { proteasome inhibitors, histone deacetylase } \\
\text { inhibitors, BCL-2 inhibitors }\end{array}$ \\
\hline MEF2D-rearranged & $\begin{array}{l}\text { Mature B cell leukemia morphology, } \\
\text { cytoplasmic } \mu \text {-chain }\end{array}$ & $\begin{array}{l}\text { Histone deacetylase inhibitors, } \\
\text { proteasome inhibitors }\end{array}$ \\
\hline TCF3-HLF & Rare; dismal prognosis & BCL-2 inhibitors \\
\hline ETV6/RUNX1-like * & $\begin{array}{l}\text { Similar gene expression profile to } \\
\text { ETV6-RUNX1 but lacks fusion }\end{array}$ & Intensification of therapy, MRD based \\
\hline \multicolumn{3}{|c|}{ T-lymphoblastic leukemia } \\
\hline Non-early T-cell precursor & $\begin{array}{l}\text { Deregulation of TAL1, TAL2, LYL1, LMO1, } \\
\text { LMO2, TLX1 (HOX11), TLX3 (HOX11L2), } \\
\text { and HOXA; NOTCH1 activating mutation }\end{array}$ & $\begin{array}{c}\text { Standard dose intensity, MRD based, } \\
\text { nelarabine, BCL-2 inhibitors }\end{array}$ \\
\hline JAK-STAT activating mutation & $\begin{array}{c}\text { Approximately } 25 \% \text { of patients } \\
\text { with T-ALL }\end{array}$ & $\begin{array}{l}\text { Standard dose intensity, MRD based, } \\
\text { nelarabine, JAK inhibitors, BCL-2 inhibitors }\end{array}$ \\
\hline$A B L 1$ fusions (e.g., NUP214-ABL1) & $\begin{array}{l}\text { Fusion with } B C R \text { and NUP214, } \\
\text { potentially amenable to tyrosine } \\
\text { kinase inhibition }\end{array}$ & $\begin{array}{l}\text { Standard dose intensity, MRD based, ABL1 } \\
\text { inhibitors, nelarabine, BCL-2 inhibitors }\end{array}$ \\
\hline Early T-cell precursor ALL & $\begin{array}{l}\text { Mutations in transcriptional regulators, } \\
\text { JAK-STAT and Ras signaling, and } \\
\text { epigenetic modifiers }\end{array}$ & $\begin{array}{l}\text { Standard dose intensity, MRD based, JAK } \\
\text { inhibitors, BCL-2 inhibitors }\end{array}$ \\
\hline
\end{tabular}

* Newly identified subgroups, necessary to confirm their prognosis in a larger number of patients. Abbreviations: MRD, minimal residual disease; iAMP21, intrachromosomal amplification of chromosome 21; ALL, acute lymphoblastic leukemia. 


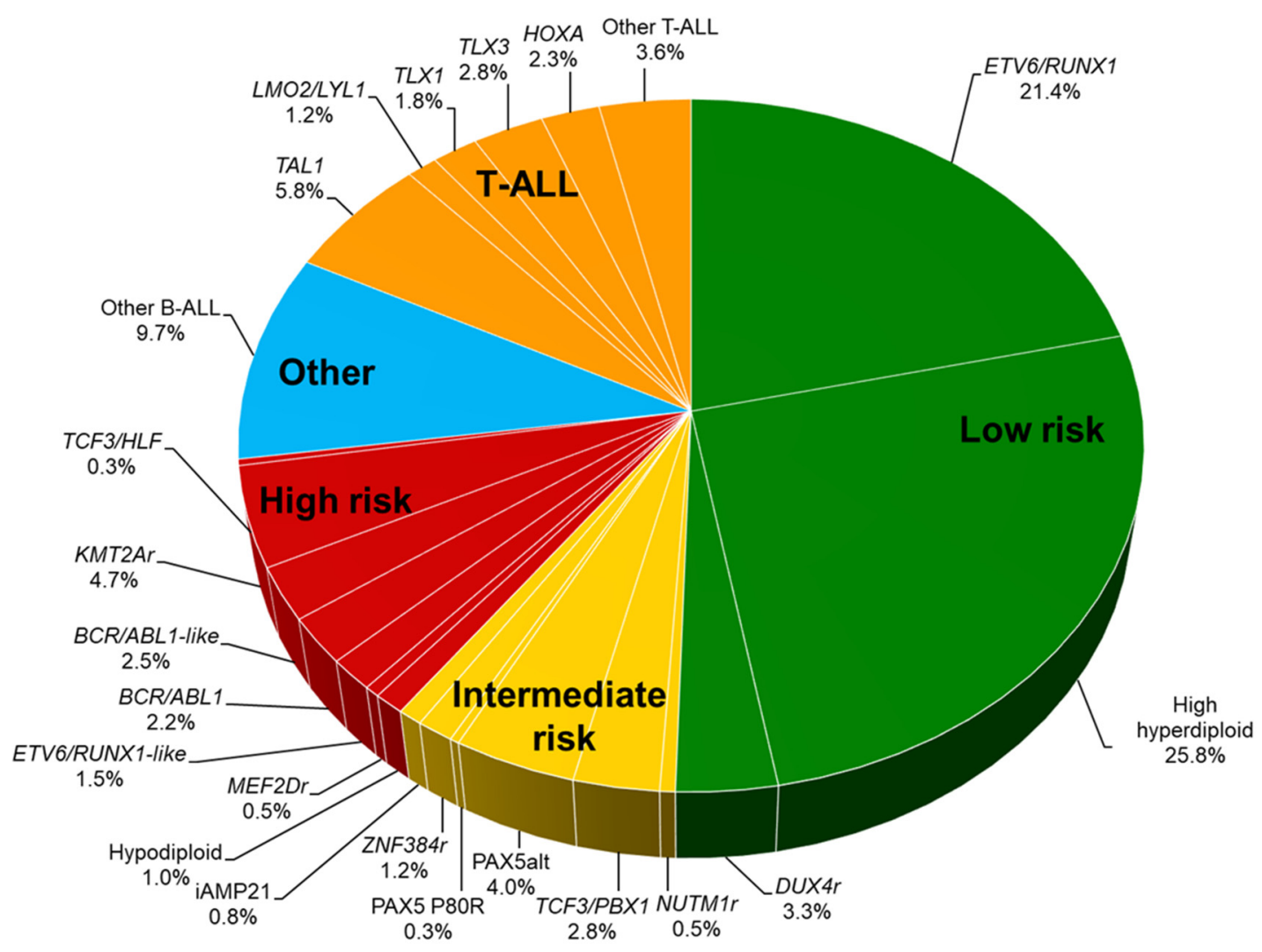

Figure 2. Distribution of genetic subtypes Genetic subgroups are listed based on the patients treated in St. Jude Total Therapy Study XVI and on patients with T-ALL who were treated in Children's Oncology Group studies and evaluated for genetics as part of the Therapeutically Applicable Research to Generate Effective Treatments initiative [11,12]. Percentages are the approximate incidence in pediatric ALL. B-ALL is categorized as low-, intermediate-, or high-risk disease. For T-ALL, no genetic subtypes are clearly associated with outcomes, but the group as a whole is considered an intermediate-risk group. Abbreviations: ALL, acute lymphoblastic leukemia.

\section{Low-Risk Genetic Subgroups}

\subsection{ETV6/RUNX1-Rearranged ALL}

ETV6/RUNX1-rearranged ALL represents approximately 20\% of pediatric ALL and is associated with excellent outcomes [13]. Up to $5 \%$ of normal newborns carry the ETV6/RUNX1 fusion at birth [14], and post-natal environmental or spontaneous oncogenic second hits are required to induce overt leukemia $[15,16]$. Patients with the ETV6/RUNX1 fusion are good candidates for reductions in the intensity of chemotherapy if their initial MRD responses are good [17,18]. A randomized study of patients with standard-risk ALL enrolled on the Associazione Italiana di Ematologia e Oncologia Pediatrica-BerlinFrankfurt-Münster (AIEOP-BFM) ALL 2000 protocol tested whether dose reductions by $30 \%$ for dexamethasone and by $50 \%$ for vincristine, doxorubicin, and cyclophosphamide during the delayed intensification phase resulted in outcomes comparable to those in the historical arm [19]. Although this study led to worse outcomes for the dose-reduction arm as a whole, outcomes in patients with ETV6/RUNX1 fusion and in those aged 1 to 6 years were equivalent for the two arms. Furthermore, in the Tokyo Children's Cancer Study Group L92-13 study, which featured only 1 year of intensive chemotherapy, only two-thirds of the enrolled patients experienced continuous remission, but those with ETV6/RUNX1 and TCF3/PBX1 rearrangements had excellent outcomes with this abbreviated therapy [20]. Notably, patients with high hyperdiploidy fared poorly in this study. 


\subsection{Hyperdiploid ALL}

Hyperdiploid ALL is the most common subtype of ALL, accounting for up to $25 \%$ of pediatric ALL. Different study groups have variously identified this subtype as having a DNA index of 1.16 or higher [21], a chromosome number of 51 to 67 [22], or trisomy of chromosomes 4 and 10 (double trisomy) [23]. Non-random gains of chromosome 4, 10, 14,17 , and 21 are common. Methotrexate is particularly useful for treating this subtype of ALL, and the disease response is influenced by the intracellular accumulation of active methotrexate polyglutamate metabolites (MTXPGs), which is higher in hyperdiploid ALL than in ETV6/RUNX1 ALL, TCF3/PBX1 ALL, or T-ALL [24-26]. This is partly due to the higher expression of the gene encoding the folate influx transporter SLC19A1 in hyperdiploid ALL, resulting from the presence of a somatically acquired additional chromosome 21 on which this gene is located. Therefore, among patients with induction failure, those with hyperdiploid ALL had better outcomes than did those in other subgroups because they responded well to high-dose methotrexate, which is typically given as post-induction therapy, and these patients can be salvaged even without a hematopoietic cell transplant (HCT) [27].

Patients with ETV6/RUNX1 fusion and hyperdiploidy and negative MRD on day 15 (as in St. Jude Total Therapy XVI) or day 19 (as in Total Therapy XV) and at the end of induction therapy have an excellent prognosis $[11,17,18]$. In St. Jude Total Therapy studies, patients with ETV6/RUNX1 fusion and hyperdiploidy are provisionally treated in the low-risk (National Cancer Institute [NCI] standard-risk) arm regardless of their age or WBC count at diagnosis, but those patients with high MRD levels on day $15(\geq 1 \%)$ or at the end of induction therapy $(\geq 0.01 \%)$ or with extramedullary (central nervous system or testis) involvement are subsequently treated in the standard-risk (NCI high-risk) arm. This approach has been successful, with excellent outcomes for both subgroups [11,13,17].

\subsection{DUX4-Rearranged ALL}

DUX4-rearranged ALL is a newly identified subtype seen in 3\% to $5 \%$ of pediatric ALL cases. The rearrangement occurs most commonly in the immunoglobulin heavy-chain locus (IGH) and results in the expression of DUX4 protein with a truncated C-terminus [28-30]. This truncated form binds an intragenic region of the ETS-family transcription factor ERG (ETS-related gene) and commonly results in the expression of a C-terminal ERG protein fragment that is a dominant-negative inhibitor of wild-type ERG function. DUX4-rearranged B-ALL has a unique immunophenotype (CD2 and CD371 positive), and a favorable outcome can be obtained, even with the deletion of IKZF1, by adjusting the intensity of the chemotherapy based on the MRD [31,32].

\section{High-Risk Genetic Subgroups in B-ALL}

\subsection{Hypodiploid ALL}

Hypodiploid ALL, which is defined by there being fewer than 44 chromosomes or a DNA index of less than 0.81 , accounts for $1 \%$ to $2 \%$ of pediatric ALL. It is associated with poor outcomes, with reported EFS of $50 \%$ to $55 \%$ [33,34]. It can be classified into three distinct subtypes: near haploid ( 24 to 31 chromosomes), low hypodiploid (32 to 39 chromosomes), and high hypodiploid (40 to 43 chromosomes). Near-haploid ALL is associated with Ras pathway mutations (particularly in NF1) and IKZF3 deletion [35]. Low-hypodiploid ALL is characterized by TP53 mutations in the leukemia cells in more than $90 \%$ of cases and also in the germline in approximately $50 \%$ of patients, in addition to the somatic alterations in IKZF2 and RB1. Therefore, patients with low-hypodiploid ALL should undergo germline testing for TP53 germline pathogenic variants (i.e., Li-Fraumeni syndrome) to enable treatment modification to avoid the use of carcinogenic agents and for genetic consultation purposes [36]. It is important to distinguish "masked" hypodiploid ALL, in which the hypodiploid clone is duplicated, from true hyperdiploid ALL, considering the possible germline TP53 mutations and the poor prognosis of hypodiploid ALL [37]. Recently, two multicenter studies demonstrated that HCT confers no benefit in hypodiploid 
ALL, particularly for patients who are MRD negative after remission-induction therapy, for whom EFS was approximately $70 \%[33,34]$. Therefore, patients with persistently positive MRD can be considered for treatment with molecular targeted agents such as BCL-2 inhibitors and PI3K inhibitors or with immunotherapy such as bispecific antibody therapy or chimeric antigen receptor (CAR) T-cell therapy [35,38,39].

\subsection{BCR/ABL1 (Philadelphia Chromosome)-Positive ALL}

$B C R / A B L 1$-positive ALL accounts for approximately $2 \%$ to $3 \%$ of pediatric ALL [40]. Before tyrosine kinase inhibitors (TKIs) became available, the survival of patients who were treated only with conventional chemotherapy was dismal, and HCT from a matched related donor or an unrelated donor during the first remission provided a cure in only approximately $50 \%$ of children [41]. The combination of the TKI imatinib with multi-agent chemotherapy significantly improved outcomes, with 5-year disease-free survival increasing to $70 \%$ in the Children's Oncology Group AALL0031 study [42]. A second-generation TKI, dasatinib, targets both the ABL1 and SRC kinases, has activity against BCR/ABL1 that is approximately 300 times more potent than that of imatinib, and can cross the blood-brain barrier [40]. The Children's Oncology Group AALL0622 study, in which dasatinib was used at $60 \mathrm{mg} / \mathrm{m}^{2} /$ day, showed no improvement in outcomes relative to those in the preceding AALL0031 study, in which imatinib $\left(340 \mathrm{mg} / \mathrm{m}^{2} /\right.$ day) was given with the same chemotherapy backbone [43]. However, the Chinese Children's Cancer Group has shown that patients who received dasatinib $\left(80 \mathrm{mg} / \mathrm{m}^{2} /\right.$ day) had significantly better EFS and OS and a lower relapse rate when compared with those who received imatinib $\left(300 \mathrm{mg} / \mathrm{m}^{2} /\right.$ day) in a randomized study [44]. Ponatinib is one of a newer generation of TKIs and has potent activity in both wild-type $B C R / A B L 1$-positive ALL and mutant forms (e.g., with the gatekeeper mutation ABL1 T315I) [40]. Treatment with ponatinib in combination with hyperfractionated cyclophosphamide, vincristine, doxorubicin, and dexamethasone (hyper-CVAD), alternating with high-dose methotrexate and cytarabine, resulted in excellent 2-year EFS in adults with newly diagnosed BCR/ABL1-positive ALL [45]. Using ponatinib in combination with a pediatric regimen that includes asparaginase and glucocorticoids can be difficult as ponatinib is also associated with an increased risk of thrombosis and pancreatitis. In adult patients with $B C R / A B L 1$-positive ALL, a chemotherapy-free regimen with glucocorticoid and dasatinib followed by blinatumomab and dasatinib was associated with a high molecular response and high survival rates with few adverse effects [46]. Nevertheless, the results of a recent preclinical study suggest that dasatinib may adversely affect the efficacy of blinatumomab [47]; additional studies are needed to determine whether these two agents should be used separately.

\subsection{BCR/ABL1 (Philadelphia Chromosome)-Like ALL}

$B C R / A B L 1$ (Philadelphia chromosome)-like ALL was initially identified as a subgroup of leukemias with a leukemic cell gene expression profile similar to that of $B C R / A B L 1$ positive ALL and frequent IKZF1 alterations but without the $B C R / A B L 1$ fusion $[48,49]$. Although the percentage can vary depending on the ethnicity of the patients, this variant occurs in approximately $3 \%$ of pediatric ALL cases and is associated with worse outcomes. It is commonly seen in patients with NCI high-risk disease; however, $B C R / A B L 1$-like ALL is also seen in patients with NCI standard-risk disease, and the outcome is associated with the MRD levels during and at the end of induction [50,51]. Many study groups have identified the genetic lesions associated with $B C R / A B L 1$-like ALL, and these are classified in three main groups: JAK-STAT signaling activating mutations, ABL1-class fusions, and alterations that are less common and that involve other kinases [52,53].

JAK-STAT signaling activating mutations constitute the largest group and are genetically more diverse [52,53]. CRLF2 rearrangements (P2RY8/CRLF2 and IGH/CRLF2) and mutations (CRLF2 F232C) lead to CRLF2 overexpression, which may be detected by flow cytometry, and these mutations are present in approximately half of BCR/ABL1-like ALL cases, being more commonly seen in patients with Native American ancestry. Most of the 
$J A K 1$ and JAK2 mutations are seen in this group. Other JAK-STAT signaling activating mutations are present in approximately $10 \%$ of $B C R / A B L 1$-like ALL cases and include $J A K 2$ fusions (translocations or interstitial deletions) that retain the tyrosine kinase domain, EPOR truncating rearrangements (e.g., with IGH, IGK, and LAIR1), IL7R insertion/deletions in the transmembrane domain, and deletions or mutations of $S H 2 B 3$ (a negative regulator of JAK-STAT signaling, the mutation of which augments JAK-STAT signaling). A JAK inhibitor, ruxolitinib, is currently being tested in clinical trials [53].

$A B L 1$-class fusions involve $A B L 1, A B L 2, C S F 1 R, P D G F R B$, and, rarely, PDGFRA and $L Y N$ and are seen in $15 \%$ to $20 \%$ of $B C R / A B L 1$-like ALL cases [52,53]. Pediatric patients with $A B L 1$-class fusions have poor outcomes when treated with regimens that do not contain a TKI, even when they receive a high-risk chemotherapy regimen and/or HCT [54]. As seen in JAK2 fusions, these are chimeric in-frame fusions that preserve the tyrosine kinase domain and are, therefore, sensitive to treatment with ABL1 inhibitors such as imatinib and dasatinib [52,55].

Other rare kinase-activating alterations include those in NTRK3, FLT3, PTK2B, and TYK2, and preclinical studies have shown the efficacy of treatment of these variants with a TRK inhibitor, an FLT3 inhibitor, an FAK inhibitor, and a TYK2 inhibitor, respectively [52,53].

\subsection{KMT2A-Rearranged $A L L$}

The KMT2A (MLL) gene is located on chromosome 11q23 and can be rearranged with more than 80 different partner genes, which are seen in both lymphoid and myeloid leukemia [56]. KMT2A-rearranged ALL is characterized by the CD10-negative pro-B cell phenotype with co-expression of myeloid markers. It accounts for approximately $5 \%$ of pediatric ALL and $75 \%$ of infant ALL. In infant ALL, KMT2A rearrangement is acquired in utero and is associated with dismal outcomes, especially in infants younger than 6 months at diagnosis with a presenting WBC count of $\geq 300 \times 10^{9} / \mathrm{L}$ or with a poor prednisone response [56]. Although two international randomized studies were performed to examine standard vs. more intensive therapy before maintenance therapy (the Interfant99 study) and myeloid- vs. lymphoid-type consolidation therapy (the Interfant-06 study), there were no significant differences in outcomes between interventions or studies [57,58]. KMT2A rearrangement results in the assembly of a unique multi-protein complex with DOT1L, BRD4, and menin [59]. Therefore, there is great potential for molecular targeted therapy with inhibitors of DOT1L, bromodomain, menin, and BCL-2. Immunotherapy with blinatumomab and autologous or allogeneic CAR T cells can be considered, although there is a possibility of a lineage switch to acute myeloid leukemia (AML) [56].

\subsection{MEF2D-Rearranged ALL}

$M E F 2 D$-rearranged ALL is seen in approximately $1 \%$ of pediatric ALL cases. The $M E F 2 D$ gene can rearrange with several partner genes: $B C L 9$ (the most common partner), CSF1R, DAZAP1, HNRNPUL1, SS18, and FOXJ2 [9,10]. MEF2D-rearranged ALL is characterized by older age at diagnosis (median, 14 years), mature B-cell leukemia morphology (large, densely basophilic, and heavily vacuolated leukemic blasts), a unique immunophenotype (weak or absent expression of CD10, high expression of CD38, and cytoplasmic immunoglobulin $\mu$-chain), and poor outcome due to early relapse [60-62]. Exogenous expression of $M E F 2 D / B C L 9$ in a B-ALL cell line promoted cell growth, increased the expression of HDAC9 (a known MEF2D target), and induced resistance to dexamethasone [60]. Patient-derived leukemia cells were sensitive to histone deacetylase inhibitors (vorinostat and panobinostat) and to a proteasome inhibitor (bortezomib) in vitro and in xenograft models. MEF2D/CSF1R can be targeted by ABL1 inhibitors.

\subsection{TCF3/HLF-Rearranged ALL}

TCF3/HLF-rearranged ALL is a rare (representing $<0.5 \%$ of cases) but very aggressive subtype of ALL. It is mostly resistant to conventional chemotherapy and has extremely poor outcomes even with intensified chemotherapy and HCT [63]. TCF3/HLF-rearranged 
ALL is characterized by enrichment of stem cell and myeloid gene signatures, PAX5 and VPREB1 deletions, and Ras pathway gene mutations. TCF3/HLF-rearrangement plays a role as a pioneer transcription factor in recruiting EP300 to drive MYC, and EP300 inhibition reduces TCF3/HLF-dependent gene expression and ALL growth [64]. Drug activity profiling and preclinical studies have shown striking activity of a BCL-2 inhibitor, venetoclax [63]. Furthermore, all of nine patients with TCF3/HLF-rearranged ALL experienced molecular remission after being treated with blinatumomab, and four of them are in longterm remission after HCT, suggesting that an immunotherapy approach can overcome the chemotherapy resistance [65].

\section{Intermediate-Risk Genetic Subtypes in B-ALL}

\subsection{TCF3/PBX1-Rearranged ALL}

TCF3/PBX1-rearranged ALL is generated with the $t(1 ; 19)(q 23 ; p 13)$ translocation and is present in approximately $2 \%$ to $5 \%$ of pediatric ALL cases, commonly expressing cytoplasmic $\mu$ chain (a pre-B phenotype) [66]. As with ETV6/RUNX1-rearranged ALL, the preleukemic TCF/PBX1 gene fusion is present in approximately $0.6 \%$ of healthy newborns [67]. The incidence of this leukemia variant is higher in African Americans [68], and a genome-wide association study identified a germline risk locus in an intergenic region between BCL11A and PAPOLG: rs2665658 [69]. In the St. Jude Total XV study, which eliminated cranial irradiation, TCF/PBX1-rearranged ALL was associated with a higher incidence of $\mathrm{CNS}$ relapse but a lower incidence of hematologic relapse compared to other forms of B-ALL $[7,66]$. In patients treated in the Total XVI study, the incidence of CNS relapse was reduced as a result of the increased frequency of early intrathecal treatments [8]. In the TCCSG L92-13 study, TCF3/PBX1-rearranged ALL had excellent outcomes with 1 year of intensive chemotherapy from diagnosis [20].

\subsection{Intrachromosomal Amplification of Chromosome 21 (iAMP21)}

Intrachromosomal amplification of chromosome 21 (iAMP21) ALL is characterized by the presence of additional copies of a region of chromosome 21 that includes RUNX1 (five or more copies per cell), and it can be associated with the germline Robertsonian translocation $\operatorname{rob}(15 ; 21)[70,71]$. iAMP21 ALL is seen in approximately $1 \%$ to $2 \%$ of pediatric ALL cases and is associated with older age (median, 9 years) and low WBC counts. Secondary cytogenetic and genetic changes include the gain of chromosome $X$, the loss or deletion of chromosome 7, ETV 6 and RB1 deletions, and SH2B2 inactivation through copy numberneutral loss of heterozygosity of chromosome 12q [72,73]. Patients with iAMP21 had dismal outcomes when treated with a low-intensity NCI standard-risk regimen $[74,75]$. Although intensified treatment has significantly improved the outcomes for these patients, their EFS remains inadequate at approximately $70 \%$. Therefore, they can also be considered candidates for recently introduced novel therapies.

\subsection{PAX5-Driven Subtypes: PAX5alt and PAX5 p.Pro80Arg}

PAX5 is the B-lymphoid transcription factor that is essential for early stages of Bcell development $[76,77]$. Germline alterations of the PAX5 gene predispose patients to ALL, and somatic alterations of PAX5 are commonly seen in pediatric ALL (e.g., PAX5 focal deletions are present in approximately $30 \%$ of ETV6/RUNX1-rearranged ALL) [77]. The two distinct disease-initiating alterations of PAX5 that result in PAX5alt and PAX5 p.Pro80Arg ALL account for approximately 3\% to 5\% and less than $1 \%$ of childhood ALL, respectively $[9,10]$. PAX5alt B-ALL is characterized by diverse PAX5 alterations, including rearrangements (most commonly with ETV6 or NOL4L), sequence mutations, and intragenic amplification. PAX5 p.Pro80Arg is characterized by universal p.Pro80Arg mutation with deletion or mutation of the remaining allele and alterations in Ras and JAK-STAT pathway genes. Patients with PAX5alt or PAX5 p.Pro80Arg B-ALL have an intermediate prognosis $[9,10]$. 


\subsection{ZNF384-Rearranged ALL}

ZNF384-rearrangement is seen in approximately $1 \%$ to $2 \%$ of childhood ALL cases and in half of $\mathrm{B} /$ myeloid mixed-phenotype acute leukemia (MPAL) cases in children. This rearrangement has more than 10 partner genes, such as EP300, TCF3, TAF15, and $C R E B B P[62,78,79]$. In B-ALL, the age of onset and the prognosis differ according to the fusion partner: with the EP300/ZNF384 fusion, the median age of onset is 11 years and outcomes are excellent, whereas with the TCF3/ZNF384 fusion, the median age of onset is 5 years and there are occasional late relapses $[78,80]$. The immunophenotype of ZNF384-rearranged B-ALL is characterized by negative or weak expression of CD10 and aberrant expression of CD13 and/or CD33 [78,80]. As with ETV6/RUNX1-rearranged and TCF3/PBX1-rearranged B-ALL, a study in monozygotic twins showed that TCF3/ZNF384 fusion can occur in utero, suggesting that a fetal hematopoietic progenitor is the cell of origin in this ALL subgroup [81]. Importantly, the secondary genomic alterations and gene expression profiles for ZNF384-rearranged B-ALL and B/myeloid MPAL cases are essentially indistinguishable, which suggests that ALL-directed therapy should be initiated for patients with newly diagnosed B/myeloid MPAL [79]. Due to its inherent lineage plasticity, ZNF384-rearranged leukemia may develop a lineage switch at relapse (from ALL to AML or vice versa) under the selective pressure of conventional chemotherapy or immunotherapy.

\section{Other Newly Identified B-ALL Subtypes}

\subsection{ETV6/RUNX1-Like ALL}

ETV6/RUNX1-like ALL is seen in 1\% to $3 \%$ of pediatric ALL cases and is particularly common in younger children $[9,10,30]$. It has a similar gene expression profile and immunophenotype to ETV6/RUNX1-rearranged ALL but lacks the ETV6/RUNX1 fusion. Within this group, alterations in ETV6, IKZF1, and TCF3 have been reported. As the number of patients identified to date is small and several relapses have been reported, it is important to evaluate the actual outcomes of patients in this group, which appear to be worse than those of patients with ETV6/RUNX1-rearranged ALL.

\subsection{NUTM1-Rearranged ALL}

NUTM1-rearranged ALL is seen in 5\% to $7 \%$ of all infants with ALL and represents $21.7 \%$ of non-KMT2A-rearranged infant ALL, but it is very rare in children (accounting for less than $1 \%$ in that population) $[9,10,82,83]$. Partner genes include ACIN1, CUX1, $B R D 9$, and ZNF618. In an international study, the 4-year OS in 45 infants and 36 children was $100 \%$, which is indicative of a favorable genetic subtype, although further studies are required to confirm this finding and to determine whether a reduction in treatment intensity is possible [82].

\section{T-Acute Lymphoblastic Leukemia}

T-ALL represents approximately $12 \%$ to $15 \%$ of pediatric ALL and is characterized by having an incidence in boys that is two to three times that in girls; a higher proportion of patients with African ancestry, in whom the rate is twice that in patients of European ancestry; high initial WBC counts; and higher frequencies of mediastinal mass and CNS involvement [12,84]. The higher incidence in boys can be partly explained by inactivating mutations or deletions of the tumor suppressor gene PHF6 on chromosome $\mathrm{X}$, which are seen in $16 \%$ of pediatric T-ALL cases [85]. The genetic alterations in T-ALL are diverse, and no clear associations with outcomes have yet been identified. Hence, unlike B-ALL, T-ALL lacks a consensus genetic classification with prognostic implications. In most cases of T-ALL, there is aberrant expression of transcription factors and oncogenes, including TAL1, TAL2, LYL1, LMO1, LMO2, TLX1 (HOX11), TLX3 (HOX11L2), and HOXA [86]. NOTCH1 activating mutations and alterations in CDKN2A/CDKN2B are seen in more than $70 \%$ of cases, and MLLT10 and KMT2A rearrangements are each seen in $5 \%$ of cases. Approximately $25 \%$ of patients have JAK-STAT activating mutations, and ABL1 fusions 
with BCR and NUP214 are occasionally detected [86]. These patients are candidates for treatment with JAK inhibitors and ABL1 inhibitors, respectively.

In most studies, the survival of patients with T-ALL is $5 \%$ to $10 \%$ worse than that of patients with B-ALL [12]. With regard to conventional chemotherapy, the treatment component of the BFM IB phase that includes cyclophosphamide, cytarabine, and mercaptopurine is of greater importance for T-ALL than for B-ALL [87]. In one study, patients with T-ALL who received nelarabine had significantly fewer incidences of CNS relapse (isolated and combined) when compared to patients who did not receive nelarabine [88]. However, approximately $90 \%$ of the total patients and all of the nelarabine-treated patients received cranial irradiation in this randomized study; therefore, the efficacy of nelarabine should be confirmed in patients whose disease is managed with intrathecal therapy only. The results of the recent randomized study of bortezomib are described below [89].

\section{Early T-Cell Precursor ALL}

Early T-cell precursor (ETP) ALL accounts for 10\% to 15\% of T-ALL, having a specific immunophenotype of early T-cell development (cytoplasmic CD3+, CD5weak, CD8-, CD1a-) with aberrant expression of myeloid and/or early progenitor cell markers [90]. The genetic features of this subtype are similar to those of hematopoietic stem cells; it is characterized by alterations in transcriptional regulators, epigenetic regulation, and JAKSTAT and Ras pathway genes [86,91]. Furthermore, ETP ALL shares genomic features with $\mathrm{T} /$ myeloid MPAL, with frequent biallelic WT1 alterations and signaling pathway mutations (e.g., in the JAK-STAT and FLT3 pathways) [79]. ETP-ALL is usually glucocorticoid resistant, has a higher incidence of induction failure, especially after the BFM IA phase [92,93], and is historically associated with worse outcomes $[90,94]$. However, ETP-ALL responds to a regimen that includes cyclophosphamide, cytarabine, and mercaptopurine (e.g., the BFM IB phase), and its outcomes are approaching those of non-ETP T-ALL $[92,93,95]$. The results of a preliminary study suggested that patients with ETP-ALL would benefit from treatment with venetoclax, a BCL-2 inhibitor [96].

\section{Minimal Residual Disease}

Although genetic subclassification is essential for risk stratification, MRD has equally important prognostic and therapeutic impact [97-99]. MRD has been quantified by multiparametric flow cytometry or by allele-specific oligonucleotide PCR analysis. The flow cytometric assay uses the leukemia-specific aberrant immunophenotype, has a typical sensitivity of $0.01 \%$, and can be applied to almost all cases of ALL $[98,99]$. It is rapid, enables accurate quantification of ALL cells, and provides an overview of the hematopoietic cell population status. However, it can be difficult to achieve sensitivity better than $0.01 \%$, and the assay may fail to detect an ALL population that has undergone a phenotypic change, especially after immunotherapy targeting CD19 and/or CD22. The PCR assay amplifies leukemia-specific fusion transcripts (available for approximately $40 \%$ of ALL cases) or immunoglobulin (Ig) or T-cell receptor (TCR) genes (available for approximately $90 \%$ of ALL cases) with a sensitivity of $0.001 \%, 10$ times that of the flow cytometry assay [98,99]. In RT-PCR analysis of fusion transcripts, there is a possibility of RNA degradation or cross-contamination from other samples. For Ig and TCR DNA, tailor-made primers are needed for each patient. Furthermore, ALL can be oligoclonal and may escape detection by clonal evolution during treatment. Recently, next-generation sequencing (NGS) of Ig or TCR genes has been applied for MRD detection (NGS MRD) with sensitivity as low as $0.0001 \%$ (equivalent to detecting one ALL cell among 1 million total cells) $[100,101]$. The use of universal primers enables the detection of clonal evolution and can also detect the background repertoire of normal B and T cells. With this technology, negative NGS MRD at the end of induction has been associated with 100\% OS among NCI standardrisk patients [102]. In pediatric patients with ALL who received HCT, negative pre-HCT MRD and post-HCT MRD were associated with significantly fewer relapses and better survival [103]. The NGS MRD assay might not be affected by phenotypic changes after 
immunotherapy, and negative NGS MRD after CAR T-cell therapy was also associated with better outcomes as compared with those in patients with positive NGS MRD among the patients with negative flow MRD [104]. These clinical benefits will result in expanded use of NGS MRD in contemporary protocols.

When considering risk stratification, clinicians should consider MRD levels in combination with genetic classification and clinical factors (e.g., age, WBC counts at diagnosis, and lineage) $[17,18,97,105]$. Patients with favorable genetic features clear MRD faster than do those with unfavorable genetics or T-ALL. Furthermore, as seen in ETV6/RUNX1rearranged and hyperdiploid ALL, some patients with favorable genetics but slow MRD clearance can be cured by intensifying their post-remission chemotherapy $[11,17,27]$. Conversely, patients with high-risk genetics have inferior outcomes even when they have undetectable MRD at the end of induction therapy $[11,17,18]$. It is also important to evaluate whether more sensitive NGS MRD can identify patients with better outcomes among those patients with high-risk genetic features. Furthermore, patients with T-ALL who had negative MRD $\left(<10^{3}\right)$ on day 78 had a cumulative risk of relapse similar to that of patients who had negative MRD on day 33 [87]. In such patients, the MRD level on day 33 was not relevant, suggesting that the MRD response to the BFM IB phase (two courses of cyclophosphamide, cytarabine, and mercaptopurine) is critical in T-ALL.

\section{Emerging Therapy: Molecular Targeted Therapy}

\subsection{Tyrosine Kinase Inhibitors}

Tyrosine kinase inhibitors have been employed in combination with standard chemotherapy to improve its efficacy (Table 1). As described earlier, ABL1 inhibitors (e.g., imatinib, dasatinib, nilotinib, and ponatinib) are used to treat patients with $B C R / A B L-$ positive ALL and ABL1-class fusions that occasionally occur in BCR/ABL-like ALL and T-ALL $[40,53,55]$. Ruxolitinib is being tested in clinical trials for patients with JAK-STAT activating mutations as seen in BCR/ABL-like ALL and T-ALL (including ETP-ALL) [53]. Currently, however, this targeted approach is limited to less than $10 \%$ of pediatric ALL cases. Further identification of ALL driving mutations and their targets will expand the use of TKIs. In this regard, ex vivo leukemia drug-sensitivity profiling identified that $44.4 \%$ of childhood T-ALL samples and $16.7 \%$ of adult T-ALL samples as being sensitive to dasatinib through the inhibition of preTCR-LCK signaling [106].

\section{2. $B C L-2$ and $B C L-X_{L}$ Inhibitors}

Members of the B-cell lymphoma 2 (BCL-2) protein family play critical roles in the intrinsic mitochondrial apoptosis pathway through interactions between pro- and antiapoptotic proteins (Table 1) [107]. Venetoclax is a selective inhibitor of BCL-2 and displaces the pro-apoptotic proteins BIM and BAX, which leads to mitochondrial outer membrane permeabilization, cytochrome $\mathrm{c}$ release, and the activation of intracellular caspases, resulting in apoptosis. Preclinical studies have shown that venetoclax is active for leukemias in the high-risk genetic group, such as KMT2A-rearranged ALL [108], hypodiploid ALL [38], $B C R / A B L$-positive ALL [109], TCF3/HLF-rearranged ALL [63], and T-ALL (including ETPALL) $[110,111]$. Low expression of CELSR2 is associated with the overexpression of BCL2 and glucocorticoid resistance in ALL cells [112]. Venetoclax mitigated glucocorticoid resistance and had synergistic effects with prednisolone and dexamethasone.

Phase I studies of venetoclax in combination with chemotherapy in pediatric and young adult patients with ALL have shown the regimen to be well tolerated with preliminary efficacies [113]. As the results of a preclinical study suggested that ALL cells were dependent on both BCL-2 and BCL- $\mathrm{X}_{\mathrm{L}}$, navitoclax (a BCL-2 and BCL- $\mathrm{X}_{\mathrm{L}}$ inhibitor) was tested in combination with venetoclax and chemotherapy for pediatric and adult patients with relapsed/refractory ALL or lymphoblastic lymphoma [114]. Among 47 heavily pre-treated patients, the complete remission rate was $60 \%$, showing the regimen to have promising efficacy. 


\subsection{Proteasome Inhibitors}

Proteasome inhibitors have shown efficacy in ALL and work synergistically with chemotherapy agents such as corticosteroids and doxorubicin (Table 1) [115]. In 22 children with relapsed ALL treated with bortezomib in combination with vincristine, dexamethasone, pegaspargase, and doxorubicin, the overall response rate was $73 \%$ [116]. In a randomized study of patients with newly diagnosed T-ALL or T-lymphoblastic lymphoma (T-LLy), adding bortezomib to the induction and delayed intensification phases was associated with better outcomes, as compared to those in patients who did not receive bortezomib, in patients with standard-risk and intermediate-risk T-ALL, as well as in those with T-LLy [89]. However, addition of bortezomib was associated with worse outcomes in patients with high-risk T-ALL. Newer proteasome inhibitors (carfilzomib and ixazomib) are under investigation.

\subsection{Other Molecular Targeted Therapies}

Dysregulation of the PI3K/AKT/mTOR pathway is frequently observed in ALL and is associated with resistance to chemotherapy $[117,118]$. mTOR inhibitors have been shown to inhibit ALL growth and reverse glucocorticoid resistance and to work synergistically with other chemotherapeutic agents, such as dexamethasone, vincristine, and doxorubicin (Table 1) [119-121]. A phase I study of everolimus with vincristine, prednisone, pegasparagase, and doxorubicin in children and adolescents with ALL in first marrow relapse occurring more than 18 months after first complete remission showed that the regimen was tolerable [122]. Nineteen ( $86 \%$ ) of 22 enrolled patients had a second complete remission, and $13(68 \%)$ of them had negative MRD.

Epigenetic modification, the biochemical alteration of chromatin, has been implicated in the pathogenesis of cancer [123]. Instead of changes in the nucleotide sequence, epigenetic modifications involve DNA methylation and histone modification, which affect the activity of genes and their cellular expression. These modifications can silence tumor suppressor genes or activate oncogenes. They are prevalent in ALL and are associated with chemotherapy resistance and relapse [124]. Epigenetic modifications may be reversible with targeted agents such as DNA methyltransferase inhibitors and histone deacetylase inhibitors (Table 1). In a phase 1 study of decitabine and vorinostat in combination with vincristine, dexamethasone, mitoxantrone, and pegaspargase, 22 children and adolescents with relapsed or refractory ALL were treated [125]. Although this regimen was associated with a high incidence of infectious complications, nine patients $(39 \%)$ had a complete response, and potent pharmacodynamic modulations of biological pathways associated with antileukemic effects were observed.

\section{Emerging Therapy: Immunotherapy}

Three major categories of immunotherapy are currently in use for pediatric ALL (Figure 3 and Table 1): bispecific antibodies (e.g., blinatumomab), CAR T cells, and antibody-drug conjugates (e.g., inotuzumab) [126]. Immunotherapy has been used mostly for B-ALL because the surface markers CD19, CD20, and CD22 are expressed only on B cells and not on hematopoietic stem cells or other tissues. Such therapy can eradicate not only B-ALL but also normal B cells, thereby causing hypogammaglobulinemia, which can be managed by intravenous or subcutaneous immunoglobulin administration. For T-ALL, antibody therapy (e.g., with daratumumab against CD38) and CAR T cells (e.g., anti-CD1a, $\mathrm{CD} 5$, and CD7) are under investigation (Figure 3). 


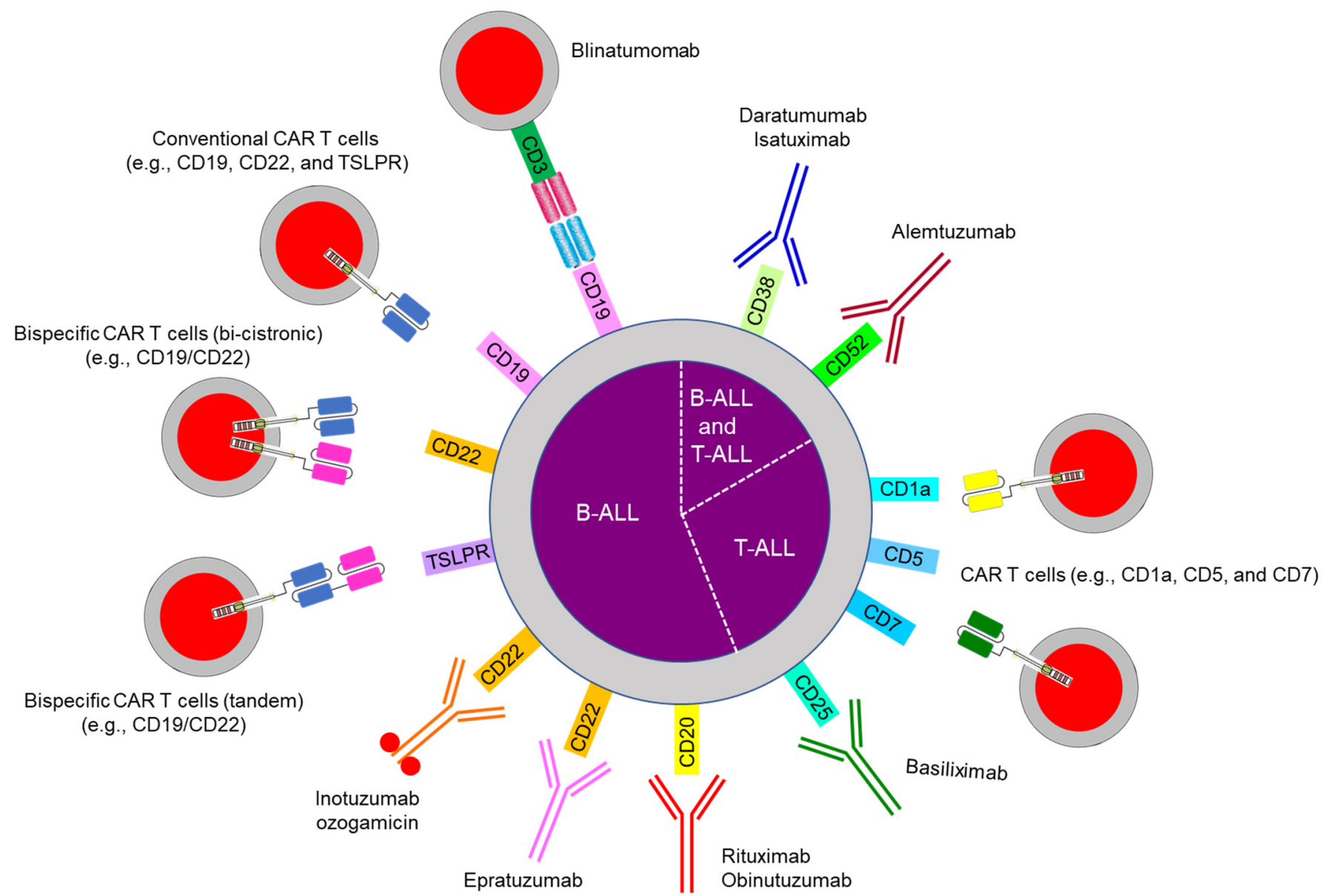

Figure 3. Immunotherapy in acute lymphoblastic leukemia. Abbreviations: ALL, acute lymphoblastic leukemia; CAR, chimeric antigen receptor; TSLPR, thymic stromal lymphopoietin receptor.

\subsection{Bispecific Antibody Therapy}

Blinatumomab has bispecific single-chain Fv fragments that link CD3+ T cells to CD19+ leukemia cells and cause a cytotoxic immune response (Figure 3 and Table 1) [127,128]. It is approved for use in pediatric and adult relapsed/refractory and MRD-positive B-ALL by the US Food and Drug Administration. The main adverse effects are cytokine release syndrome and neurotoxicity, which coincide with $\mathrm{T}$ cell activation. Two randomized studies in children, adolescents, and young adults with intermediate-risk or high-risk relapsed/refractory B-ALL showed blinatumomab to have benefits over intensive consolidation chemotherapy $[129,130]$. The loss of CD19 expression is a major mechanism of resistance to blinatumomab treatment and is also observed with CAR T cell therapy. Acquired genetic mutations in CD19 exons 2-5 or alternative splicing at exon 2 produce a truncated protein with a nonfunctional or absent transmembrane domain and/or no antibody binding site $[131,132]$. Sustained CD19-antibody pressure can result in lineage switches as described in KMT2A- and ZNF384-rearranged B-ALL [133,134]. An alteration in CD81, which is a chaperone protein for the maturation and trafficking of the CD19 molecule from the Golgi apparatus to the cell surface, has been also reported [135].

\subsection{Chimeric Antigen Receptor (CAR) T Cells}

CAR T cells express single-chain Fv fragments against B-lineage markers (e.g., CD19, CD22, or both) with intracellular signaling domains such as 4-1BB or CD28 with CD3 [ [136]. A phase 2 international study of anti-CD19 CAR T cells (tisagenlecleucel) in pediatric and young adult patients with relapsed/refractory B-ALL showed a complete remission rate of $81 \%$ at 3 months and EFS and OS of $73 \%$ and $90 \%$, respectively, at 6 months [137]. Currently, 
tisagenlecleucel is approved for patients up to 25 years of age with B-ALL that is refractory or in a second or later relapse. Several groups consider CAR T cells to be curative therapy, although others view them as a bridging therapy to HCT. As with blinatumomab, cytokine release syndrome and neurotoxicity are commonly seen with CAR T-cell therapy [138]. Preemptive administration of tocilizumab (an anti-IL-6 receptor antibody) decrease the incidence of severe cytokine release syndrome without compromising the efficacy of CAR T cells [139]. CAR T-cell recipients are also at high risk for infection, and they should be considered for bacterial and fungal prophylaxis until their neutropenia resolves, in addition to immunoglobulin supplement and Pneumocystis jirovecii pneumonia prophylaxis [140].

Mechanisms of resistance to CAR T-cell therapy include the loss of CAR T-cell persistence and B-cell aplasia and antigen loss on ALL cells [141,142]. In the former scenario, the type of co-stimulatory molecule (e.g., $4-1 \mathrm{BB}$ vs. CD28), rejection due to the murine component in tisagenlecleucel, and T-cell exhaustion are considered important factors. The use of two co-stimulatory molecules or new types of co-stimulatory molecule; humanized CAR T cells; in vivo stimulation with a CD19 vaccine, cytokines, or check point inhibitors; or early collection of $\mathrm{T}$ cells during treatment for high-risk patients may overcome this issue. With regard to target antigen loss, CAR T cells that can target other antigens (e.g., CD22 or the thymic stromal lymphopoietin receptor) or that can simultaneously target dual antigens (e.g., CD19/CD22) and the administration of two independent CAR T cells that target different antigens are being investigated [143-147].

For extramedullary relapse (e.g., in the CNS and testes), CAR T cells can migrate and show anti-leukemia effects; therefore, they can be considered not only for isolated bone marrow relapses but also for isolated or combined extramedullary relapses, thereby avoiding radiation therapy $[148,149]$.

\subsection{Antibody-Drug Conjugates}

Inotuzumab ozogamicin is an anti-CD22 antibody that is linked to calicheamicin, a cytotoxic antitumor antibiotic that causes double-strand DNA breaks [150]. Inotuzumab is currently approved for use in adult patients with relapsed/refractory B-ALL. It is associated with sinusoidal obstruction syndrome, especially after HCT [150]. Fractionated weekly dosing of inotuzumab at the dose lower than a single dose given every $3-4$ weeks and a longer interval between inotuzumab administration and HCT (i.e., 2 months or more) can reduce the incidence of this syndrome [151]. Additionally, it is recommended to use prophylactic pharmacologic agents (e.g., ursodiol), to limit the inotuzumab use to two cycles if HCT is planned, and to avoid HCT conditioning regimens that contain dual alkylating agents (e.g., thiotepa and melphalan) and concomitant hepatotoxic drugs (e.g., azoles) [152]. In a pediatric phase I study that used fractionated weekly dosing for relapsed/refractory B-ALL, complete remission was seen in $80 \%$ of the patients and $84 \%$ of those with available flow cytometry data had negative MRD [153].

\section{Conclusions}

The diagnosis of ALL, the treatment of patients, and the evaluation of the treatment response have undergone remarkable improvement. The detailed genetic characterization of ALL cells, functional genomics and proteomics, and drug sensitivity assays with ex vivo and patient-derived xenograft (PDX) models for molecular targeted agents and immunotherapy will lead to new therapeutic strategies. Furthermore, the evaluation of germline genetics can lead to an understanding of leukemogenesis, cancer predisposition, and the differences in drug response and metabolism (pharmacogenomics). Basic, translational, and clinical research on ALL will not end until all patients can be cured without acute complications or late sequelae.

Author Contributions: Conceptualization, H.I. and C.-H.P.; data curation, H.I.; writing-original draft preparation, H.I.; writing-review and editing, H.I. and C.-H.P.; funding acquisition, H.I. and C.-H.P. All authors have read and agreed to the published version of the manuscript. 
Funding: Supported in part by Cancer Center Core Grant CA21765 from the National Institutes of Health and by the American Lebanese Syrian Associated Charities (ALSAC). The funding organizations had no role in the design and conduct of the review; the collection, management, analysis, and interpretation of the data; the preparation, review, or approval of the manuscript; or the decision to submit the manuscript for publication. The content is solely the responsibility of the authors and does not necessarily represent the official views of the National Institutes of Health.

Institutional Review Board Statement: Not applicable.

Informed Consent Statement: Not applicable.

Data Availability Statement: Data sharing not applicable.

Acknowledgments: The authors thank Keith A. Laycock for scientific editing of the manuscript.

Conflicts of Interest: The authors have no conflict of interest, including specific financial interests, relationships, or affiliations relevant to the subject of this manuscript.

\section{References}

1. Hunger, S.P.; Mullighan, C.G. Acute Lymphoblastic Leukemia in Children. N. Engl. J. Med. 2015, 373, 1541-1552. [CrossRef] [PubMed]

2. Inaba, H.; Greaves, M.; Mullighan, C.G. Acute lymphoblastic leukaemia. Lancet 2013, 381, 1943-1955. [CrossRef]

3. Pui, C.H.; Nichols, K.E.; Yang, J.J. Somatic and germline genomics in paediatric acute lymphoblastic leukaemia. Nat. Rev. Clin. Oncol. 2019, 16, 227-240. [CrossRef]

4. Malard, F.; Mohty, M. Acute lymphoblastic leukaemia. Lancet 2020, 395, 1146-1162. [CrossRef]

5. National Cancer Institute. Age-Adjusted and Age-Specific SEER Cancer Incidence Rates, 2014-2018. Available online: https: //seer.cancer.gov/csr/1975_2018/results_merged/sect_02_childhood_cancer_iccc.pdf (accessed on 18 April 2021).

6. Lim, J.Y.; Bhatia, S.; Robison, L.L.; Yang, J.J. Genomics of racial and ethnic disparities in childhood acute lymphoblastic leukemia. Cancer 2014, 120, 955-962. [CrossRef]

7. Pui, C.H.; Campana, D.; Pei, D.; Bowman, W.P.; Sandlund, J.T.; Kaste, S.C.; Ribeiro, R.C.; Rubnitz, J.E.; Raimondi, S.C.; Onciu, M.; et al. Treating childhood acute lymphoblastic leukemia without cranial irradiation. N. Engl. J. Med. 2009, 360, $2730-2741$. [CrossRef]

8. Jeha, S.; Pei, D.; Choi, J.; Cheng, C.; Sandlund, J.T.; Coustan-Smith, E.; Campana, D.; Inaba, H.; Rubnitz, J.E.; Ribeiro, R.C.; et al. Improved CNS control of childhood acute lymphoblastic leukemia without cranial irradiation: St Jude Total Therapy Study 16. J. Clin. Oncol. 2019, 37, 3377-3391. [CrossRef]

9. Gu, Z.; Churchman, M.L.; Roberts, K.G.; Moore, I.; Zhou, X.; Nakitandwe, J.; Hagiwara, K.; Pelletier, S.; Gingras, S.; Berns, H.; et al. PAX5-driven subtypes of B-progenitor acute lymphoblastic leukemia. Nat. Genet. 2019, 51, 296-307. [CrossRef]

10. Li, J.F.; Dai, Y.T.; Lilljebjörn, H.; Shen, S.H.; Cui, B.W.; Bai, L.; Liu, Y.F.; Qian, M.X.; Kubota, Y.; Kiyoi, H.; et al. Transcriptional landscape of B cell precursor acute lymphoblastic leukemia based on an international study of 1223 cases. Proc. Natl. Acad. Sci. USA 2018, 115, E11711-E11720. [CrossRef]

11. Jeha, S.; Choi, J.; Roberts, K.G.; Pei, D.; Coustan-Smith, E.; Inaba, H.; Rubnitz, J.E.; Ribeiro, R.C.; Gruber, T.A.; Raimondi, S.C.; et al. Clinical significance of novel subtypes of acute lymphoblastic leukemia in the context of minimal residual disease-directed therapy. Blood Cancer Discov. 2021, in press. [CrossRef]

12. Teachey, D.T.; Pui, C.H. Comparative features and outcomes between paediatric T-cell and B-cell acute lymphoblastic leukaemia. Lancet Oncol. 2019, 20, e142-e154. [CrossRef]

13. Bhojwani, D.; Pei, D.; Sandlund, J.T.; Jeha, S.; Ribeiro, R.C.; Rubnitz, J.E.; Raimondi, S.C.; Shurtleff, S.; Onciu, M.; Cheng, C.; et al. ETV6-RUNX1-positive childhood acute lymphoblastic leukemia: Improved outcome with contemporary therapy. Leukemia 2012, 26, 265-270. [CrossRef] [PubMed]

14. Schäfer, D.; Olsen, M.; Lähnemann, D.; Stanulla, M.; Slany, R.; Schmiegelow, K.; Borkhardt, A.; Fischer, U. Five percent of healthy newborns have an ETV6-RUNX1 fusion as revealed by DNA-based GIPFEL screening. Blood 2018, 131, 821-826. [CrossRef] [PubMed]

15. Alpar, D.; Wren, D.; Ermini, L.; Mansur, M.B.; van Delft, F.W.; Bateman, C.M.; Titley, I.; Kearney, L.; Szczepanski, T.; Gonzalez, D.; et al. Clonal origins of ETV6-RUNX1 ${ }^{+}$acute lymphoblastic leukemia: Studies in monozygotic twins. Leukemia 2015, 29, 839-846. [CrossRef] [PubMed]

16. Rodríguez-Hernández, G.; Hauer, J.; Martín-Lorenzo, A.; Scháfer, D.; Bartenhagen, C.; García-Ramírez, I.; Auer, F.; GonzálezHerrero, I.; Ruiz-Roca, L.; Gombert, M.; et al. Infection exposure promotes ETV6-RUNX1 precursor B-cell leukemia via impaired H3K4 demethylases. Cancer Res. 2017, 77, 4365-4377. [CrossRef]

17. Pui, C.H.; Pei, D.; Raimondi, S.C.; Coustan-Smith, E.; Jeha, S.; Cheng, C.; Bowman, W.P.; Sandlund, J.T.; Ribeiro, R.C.; Rubnitz, J.E.; et al. Clinical impact of minimal residual disease in children with different subtypes of acute lymphoblastic leukemia treated with Response-Adapted therapy. Leukemia 2017, 31, 333-339. [CrossRef] 
18. O'Connor, D.; Enshaei, A.; Bartram, J.; Hancock, J.; Harrison, C.J.; Hough, R.; Samarasinghe, S.; Schwab, C.; Vora, A.; Wade, R.; et al. Genotype-specific minimal residual disease interpretation improves stratification in pediatric acute lymphoblastic leukemia. J. Clin. Oncol. 2018, 36, 34-43. [CrossRef] [PubMed]

19. Schrappe, M.; Bleckmann, K.; Zimmermann, M.; Biondi, A.; Möricke, A.; Locatelli, F.; Cario, G.; Rizzari, C.; Attarbaschi, A.; Valsecchi, M.G.; et al. Reduced-intensity delayed intensification in standard-risk pediatric acute lymphoblastic leukemia defined by undetectable minimal residual disease: Results of an international randomized trial (AIEOP-BFM ALL 2000). J. Clin. Oncol. 2018, 36, 244-253. [CrossRef]

20. Kato, M.; Ishimaru, S.; Seki, M.; Yoshida, K.; Shiraishi, Y.; Chiba, K.; Kakiuchi, N.; Sato, Y.; Ueno, H.; Tanaka, H.; et al. Long-term outcome of 6-month maintenance chemotherapy for acute lymphoblastic leukemia in children. Leukemia 2017, 31, 580-584. [CrossRef]

21. Look, A.T.; Roberson, P.K.; Williams, D.L.; Rivera, G.; Bowman, W.P.; Pui, C.H.; Ochs, J.; Abromowitch, M.; Kalwinsky, D.; Dahl, G.V.; et al. Prognostic importance of blast cell DNA content in childhood acute lymphoblastic leukemia. Blood 1985, 65, $1079-1086$. [CrossRef] [PubMed]

22. Williams, D.L.; Tsiatis, A.; Brodeur, G.M.; Look, A.T.; Melvin, S.L.; Bowman, W.P.; Kalwinsky, D.K.; Rivera, G.; Dahl, G.V. Prognostic importance of chromosome number in 136 untreated children with acute lymphoblastic leukemia. Blood 1982, 60, 864-871. [CrossRef] [PubMed]

23. Harris, M.B.; Shuster, J.J.; Carroll, A.; Look, A.T.; Borowitz, M.J.; Crist, W.M.; Nitschke, R.; Pullen, J.; Steuber, C.P.; Land, V.J. Trisomy of leukemic cell chromosomes 4 and 10 identifies children with B-progenitor cell acute lymphoblastic leukemia with a very low risk of treatment failure: A Pediatric Oncology Group study. Blood 1992, 79, 3316-3324. [CrossRef]

24. Whitehead, V.M.; Vuchich, M.J.; Lauer, S.J.; Mahoney, D.; Carroll, A.J.; Shuster, J.J.; Esseltine, D.W.; Payment, C.; Look, A.T.; Akabutu, J.; et al. Accumulation of high levels of methotrexate polyglutamates in lymphoblasts from children with hyperdiploid (greater than 50 chromosomes) B-lineage acute lymphoblastic leukemia: A Pediatric Oncology Group study. Blood 1992, 80, 1316-1323. [CrossRef] [PubMed]

25. Kager, L.; Cheok, M.; Yang, W.; Zaza, G.; Cheng, Q.; Panetta, J.C.; Pui, C.H.; Downing, J.R.; Relling, M.V.; Evans, W.E. Folate pathway gene expression differs in subtypes of acute lymphoblastic leukemia and influences methotrexate pharmacodynamics. $J$. Clin. Investig. 2005, 115, 110-117. [CrossRef] [PubMed]

26. Lopez-Lopez, E.; Autry, R.J.; Smith, C.; Yang, W.; Paugh, S.W.; Panetta, J.C.; Crews, K.R.; Bonten, E.J.; Smart, B.; Pei, D.; et al. Pharmacogenomics of intracellular methotrexate polyglutamates in patients' leukemia cells in vivo. J. Clin. Investig. 2020, 130, 6600-6615. [CrossRef] [PubMed]

27. Schrappe, M.; Hunger, S.P.; Pui, C.H.; Saha, V.; Gaynon, P.S.; Baruchel, A.; Conter, V.; Otten, J.; Ohara, A.; Versluys, A.B.; et al. Outcomes after induction failure in childhood acute lymphoblastic leukemia. N. Engl. J. Med. 2012, 366, 1371-1381. [CrossRef] [PubMed]

28. Yasuda, T.; Tsuzuki, S.; Kawazu, M.; Hayakawa, F.; Kojima, S.; Ueno, T.; Imoto, N.; Kohsaka, S.; Kunita, A.; Doi, K.; et al. Recurrent DUX4 fusions in B cell acute lymphoblastic leukemia of adolescents and young adults. Nat. Genet. 2016, 48, 569-574. [CrossRef]

29. Zhang, J.; McCastlain, K.; Yoshihara, H.; Xu, B.; Chang, Y.; Churchman, M.L.; Wu, G.; Li, Y.; Wei, L.; Iacobucci, I.; et al. Deregulation of DUX4 and ERG in acute lymphoblastic leukemia. Nat. Genet. 2016, 48, 1481-1489. [CrossRef]

30. Lilljebjörn, H.; Henningsson, R.; Hyrenius-Wittsten, A.; Olsson, L.; Orsmark-Pietras, C.; von Palffy, S.; Askmyr, M.; Rissler, M.; Schrappe, M.; Cario, G.; et al. Identification of ETV6-RUNX1-like and DUX4-rearranged subtypes in paediatric B-cell precursor acute lymphoblastic leukaemia. Nat. Commun. 2016, 7, 11790. [CrossRef]

31. Schinnerl, D.; Mejstrikova, E.; Schumich, A.; Zaliova, M.; Fortschegger, K.; Nebral, K.; Attarbaschi, A.; Fiser, K.; Kauer, M.O.; Popitsch, N.; et al. CD371 cell surface expression: A unique feature of DUX4-rearranged acute lymphoblastic leukemia. Haematologica 2019, 104, e352-e355. [CrossRef]

32. Stanulla, M.; Dagdan, E.; Zaliova, M.; Möricke, A.; Palmi, C.; Cazzaniga, G.; Eckert, C.; Te Kronnie, G.; Bourquin, J.P.; Bornhauser, B.; et al. IKZF1 ${ }^{\text {plus }}$ defines a new minimal residual disease-dependent very-poor prognostic profile in pediatric B-cell precursor acute lymphoblastic leukemia. J. Clin. Oncol. 2018, 36, 1240-1249. [CrossRef]

33. Pui, C.H.; Rebora, P.; Schrappe, M.; Attarbaschi, A.; Baruchel, A.; Basso, G.; Cave, H.; Elitzur, S.; Koh, K.; Liu, H.C.; et al. Outcome of children with hypodiploid acute lymphoblastic leukemia: A retrospective multinational study. J. Clin. Oncol. 2019, 37, 770-779. [CrossRef] [PubMed]

34. McNeer, J.L.; Devidas, M.; Dai, Y.; Carroll, A.J.; Heerema, N.A.; Gastier-Foster, J.M.; Kahwash, S.B.; Borowitz, M.J.; Wood, B.L.; Larsen, E.; et al. Hematopoietic stem-cell transplantation does not improve the poor outcome of children with hypodiploid acute lymphoblastic leukemia: A report from Children's Oncology Group. J. Clin. Oncol. 2019, 37, 780-789. [CrossRef]

35. Holmfeldt, L.; Wei, L.; Diaz-Flores, E.; Walsh, M.; Zhang, J.; Ding, L.; Payne-Turner, D.; Churchman, M.; Andersson, A.; Chen, S.C.; et al. The genomic landscape of hypodiploid acute lymphoblastic leukemia. Nat. Genet. 2013, 45, 242-252. [CrossRef]

36. Qian, M.; Cao, X.; Devidas, M.; Yang, W.; Cheng, C.; Dai, Y.; Carroll, A.; Heerema, N.A.; Zhang, H.; Moriyama, T.; et al. TP53 germline variations influence the predisposition and prognosis of B-cell acute lymphoblastic leukemia in children. J. Clin. Oncol. 2018, 36, 591-599. [CrossRef] [PubMed]

37. Safavi, S.; Paulsson, K. Near-haploid and low-hypodiploid acute lymphoblastic leukemia: Two distinct subtypes with consistently poor prognosis. Blood 2017, 129, 420-423. [CrossRef] 
38. Diaz-Flores, E.; Comeaux, E.Q.; Kim, K.L.; Melnik, E.; Beckman, K.; Davis, K.L.; Wu, K.; Akutagawa, J.; Bridges, O.; Marino, R.; et al. Bcl-2 is a therapeutic target for hypodiploid B-lineage acute lymphoblastic leukemia. Cancer Res. 2019, 79, $2339-2351$. [CrossRef] [PubMed]

39. Talleur, A.C.; Maude, S.L. What is the role for HSCT or immunotherapy in pediatric hypodiploid B-cell acute lymphoblastic leukemia? Hematol. Am. Soc. Hematol. Educ. Program. 2020, 2020, 508-511. [CrossRef]

40. Slayton, W.B.; Schultz, K.R.; Silverman, L.B.; Hunger, S.P. How we approach Philadelphia chromosome-positive acute lymphoblastic leukemia in children and young adults. Pediatr. Blood Cancer 2020, 67, e28543. [CrossRef]

41. Aricò, M.; Schrappe, M.; Hunger, S.P.; Carroll, W.L.; Conter, V.; Galimberti, S.; Manabe, A.; Saha, V.; Baruchel, A.; Vettenranta, K.; et al. Clinical outcome of children with newly diagnosed Philadelphia chromosome-positive acute lymphoblastic leukemia treated between 1995 and 2005. J. Clin. Oncol. 2010, 28, 4755-4761. [CrossRef]

42. Schultz, K.R.; Carroll, A.; Heerema, N.A.; Bowman, W.P.; Aledo, A.; Slayton, W.B.; Sather, H.; Devidas, M.; Zheng, H.W.; Davies, S.M.; et al. Long-term follow-up of imatinib in pediatric Philadelphia chromosome-positive acute lymphoblastic leukemia: Children's Oncology Group study AALL0031. Leukemia 2014, 28, 1467-1471. [CrossRef]

43. Slayton, W.B.; Schultz, K.R.; Kairalla, J.A.; Devidas, M.; Mi, X.; Pulsipher, M.A.; Chang, B.H.; Mullighan, C.; Iacobucci, I.; Silverman, L.B.; et al. Dasatinib plus intensive chemotherapy in children, adolescents, and young adults with Philadelphia chromosome-positive acute lymphoblastic leukemia: Results of Children's Oncology Group trial AALL0622. J. Clin. Oncol. 2018, 36, 2306-2314. [CrossRef]

44. Shen, S.; Chen, X.; Cai, J.; Yu, J.; Gao, J.; Hu, S.; Zhai, X.; Liang, C.; Ju, X.; Jiang, H.; et al. Effect of dasatinib vs. imatinib in the treatment of pediatric philadelphia chromosome-positive acute lymphoblastic leukemia: A randomized clinical trial. JAMA Oncol. 2020, 6, 358-366. [CrossRef] [PubMed]

45. Jabbour, E.; Kantarjian, H.; Ravandi, F.; Thomas, D.; Huang, X.; Faderl, S.; Pemmaraju, N.; Daver, N.; Garcia-Manero, G.; Sasaki, K.; et al. Combination of hyper-CVAD with ponatinib as first-line therapy for patients with Philadelphia chromosome-positive acute lymphoblastic leukaemia: A single-centre, phase 2 study. Lancet Oncol. 2015, 16, 1547-1555. [CrossRef]

46. Foà, R.; Bassan, R.; Vitale, A.; Elia, L.; Piciocchi, A.; Puzzolo, M.C.; Canichella, M.; Viero, P.; Ferrara, F.; Lunghi, M.; et al. Dasatinibblinatumomab for Ph-positive acute lymphoblastic leukemia in adults. N. Engl. J. Med. 2020, 383, 1613-1623. [CrossRef] [PubMed]

47. Leonard, J.T.; Kosaka, Y.; Malla, P.; LaTocha, D.; Lamble, A.; Hayes-Lattin, B.; Byrd, K.; Druker, B.J.; Tyner, J.W.; Chang, B.H.; et al. Concomitant use of a dual Src/ABL kinase inhibitor eliminates the in vitro efficacy of blinatumomab against Ph+ ALL. Blood 2021, 137, 939-944. [CrossRef] [PubMed]

48. Mullighan, C.G.; Su, X.; Zhang, J.; Radtke, I.; Phillips, L.A.; Miller, C.B.; Ma, J.; Liu, W.; Cheng, C.; Schulman, B.A.; et al. Deletion of IKZF1 and prognosis in acute lymphoblastic leukemia. N. Engl. J. Med. 2009, 360, 470-480. [CrossRef]

49. Den Boer, M.L.; van Slegtenhorst, M.; de Menezes, R.X.; Cheok, M.H.; Buijs-Gladdines, J.G.; Peters, S.T.; van Zutven, L.J.; Beverloo, H.B.; van der Spek, P.J.; Escherich, G.; et al. A subtype of childhood acute lymphoblastic leukaemia with poor treatment outcome: A genome-wide classification study. Lancet Oncol. 2009, 10, 125-134. [CrossRef]

50. Roberts, K.G.; Pei, D.; Campana, D.; Payne-Turner, D.; Li, Y.; Cheng, C.; Sandlund, J.T.; Jeha, S.; Easton, J.; Becksfort, J.; et al. Outcomes of children with $B C R-A B L 1$-like acute lymphoblastic leukemia treated with risk-directed therapy based on the levels of minimal residual disease. J. Clin. Oncol. 2014, 32, 3012-3020. [CrossRef]

51. Roberts, K.G.; Reshmi, S.C.; Harvey, R.C.; Chen, I.M.; Patel, K.; Stonerock, E.; Jenkins, H.; Dai, Y.; Valentine, M.; Gu, Z.; et al. Genomic and outcome analyses of Ph-like ALL in NCI standard-risk patients: A report from the Children's Oncology Group. Blood 2018, 132, 815-824. [CrossRef]

52. Roberts, K.G.; Li, Y.; Payne-Turner, D.; Harvey, R.C.; Yang, Y.L.; Pei, D.; McCastlain, K.; Ding, L.; Lu, C.; Song, G.; et al. Targetable kinase-activating lesions in Ph-like acute lymphoblastic leukemia. N. Engl. J. Med. 2014, 371, 1005-1015. [CrossRef] [PubMed]

53. Tasian, S.K.; Loh, M.L.; Hunger, S.P. Philadelphia chromosome-like acute lymphoblastic leukemia. Blood 2017, 130, $2064-2072$. [CrossRef] [PubMed]

54. Den Boer, M.L.; Cario, G.; Moorman, A.V.; Boer, J.M.; de Groot-Kruseman, H.A.; Fiocco, M.; Escherich, G.; Imamura, T.; Yeoh, A.; Sutton, R.; et al. Outcomes of paediatric patients with B-cell acute lymphocytic leukaemia with ABL-class fusion in the pre-tyrosine-kinase inhibitor era: A multicentre, retrospective, cohort study. Lancet Haematol. 2021, 8, e55-e66. [CrossRef]

55. Tanasi, I.; Ba, I.; Sirvent, N.; Braun, T.; Cuccuini, W.; Ballerini, P.; Duployez, N.; Tanguy-Schmidt, A.; Tamburini, J.; Maury, S.; et al. Efficacy of tyrosine kinase inhibitors in Ph-like acute lymphoblastic leukemia harboring ABL-class rearrangements. Blood 2019, 134, 1351-1355. [CrossRef] [PubMed]

56. Brown, P.; Pieters, R.; Biondi, A. How I treat infant leukemia. Blood 2019, 133, 205-214. [CrossRef] [PubMed]

57. Pieters, R.; Schrappe, M.; De Lorenzo, P.; Hann, I.; De Rossi, G.; Felice, M.; Hovi, L.; LeBlanc, T.; Szczepanski, T.; Ferster, A.; et al. A treatment protocol for infants younger than 1 year with acute lymphoblastic leukaemia (Interfant-99): An observational study and a multicentre randomised trial. Lancet 2007, 370, 240-250. [CrossRef]

58. Pieters, R.; De Lorenzo, P.; Ancliffe, P.; Aversa, L.A.; Brethon, B.; Biondi, A.; Campbell, M.; Escherich, G.; Ferster, A.; Gardner, R.A.; et al. Outcome of infants younger than 1 year with acute lymphoblastic leukemia treated with the Interfant-06 protocol: Results from an international phase III randomized study. J. Clin. Oncol. 2019, 37, 2246-2256. [CrossRef] [PubMed]

59. Neff, T.; Armstrong, S.A. Recent progress toward epigenetic therapies: The example of mixed lineage leukemia. Blood 2013, 121, 4847-4853. [CrossRef] [PubMed] 
60. Suzuki, K.; Okuno, Y.; Kawashima, N.; Muramatsu, H.; Okuno, T.; Wang, X.; Kataoka, S.; Sekiya, Y.; Hamada, M.; Murakami, N.; et al. MEF2D-BCL9 fusion gene is associated with high-risk acute B-cell precursor lymphoblastic leukemia in adolescents. J. Clin. Oncol. 2016, 34, 3451-3459. [CrossRef]

61. Ohki, K.; Kiyokawa, N.; Saito, Y.; Hirabayashi, S.; Nakabayashi, K.; Ichikawa, H.; Momozawa, Y.; Okamura, K.; Yoshimi, A.; Ogata-Kawata, H.; et al. Clinical and molecular characteristics of MEF2D fusion-positive B-cell precursor acute lymphoblastic leukemia in childhood, including a novel translocation resulting in MEF2D-HNRNPH1 gene fusion. Haematologica 2019, 104, 128-137. [CrossRef]

62. Liu, Y.F.; Wang, B.Y.; Zhang, W.N.; Huang, J.Y.; Li, B.S.; Zhang, M.; Jiang, L.; Li, J.F.; Wang, M.J.; Dai, Y.J.; et al. Genomic profiling of adult and pediatric B-cell acute lymphoblastic leukemia. EBioMedicine 2016, 8, 173-183. [CrossRef] [PubMed]

63. Fischer, U.; Forster, M.; Rinaldi, A.; Risch, T.; Sungalee, S.; Warnatz, H.J.; Bornhauser, B.; Gombert, M.; Kratsch, C.; Stütz, A.M.; et al. Genomics and drug profiling of fatal TCF3-HLF-positive acute lymphoblastic leukemia identifies recurrent mutation patterns and therapeutic options. Nat. Genet. 2015, 47, 1020-1029. [CrossRef]

64. Huang, Y.; Mouttet, B.; Warnatz, H.J.; Risch, T.; Rietmann, F.; Frommelt, F.; Ngo, Q.A.; Dobay, M.P.; Marovca, B.; Jenni, S.; et al. The leukemogenic TCF3-HLF complex rewires enhancers driving cellular identity and self-renewal conferring EP300 vulnerability. Cancer Cell 2019, 36, 630-644.e639. [CrossRef]

65. Mouttet, B.; Vinti, L.; Ancliff, P.; Bodmer, N.; Brethon, B.; Cario, G.; Chen-Santel, C.; Elitzur, S.; Hazar, V.; Kunz, J.; et al. Durable remissions in TCF3-HLF positive acute lymphoblastic leukemia with blinatumomab and stem cell transplantation. Haematologica 2019, 104, e244-e247. [CrossRef]

66. Jeha, S.; Pei, D.; Raimondi, S.C.; Onciu, M.; Campana, D.; Cheng, C.; Sandlund, J.T.; Ribeiro, R.C.; Rubnitz, J.E.; Howard, S.C.; et al. Increased risk for CNS relapse in pre-B cell leukemia with the $t(1 ; 19) / T C F 3-P B X 1$. Leukemia 2009, 23, 1406-1409. [CrossRef] [PubMed]

67. Hein, D.; Dreisig, K.; Metzler, M.; Izraeli, S.; Schmiegelow, K.; Borkhardt, A.; Fischer, U. The preleukemic TCF3-PBX1 gene fusion can be generated in utero and is present in $\approx 0.6 \%$ of healthy newborns. Blood 2019, 134, 1355-1358. [CrossRef]

68. Pui, C.H.; Sandlund, J.T.; Pei, D.; Rivera, G.K.; Howard, S.C.; Ribeiro, R.C.; Rubnitz, J.E.; Razzouk, B.I.; Hudson, M.M.; Cheng, C.; et al. Results of therapy for acute lymphoblastic leukemia in black and white children. JAMA 2003, 290, 2001-2007. [CrossRef] [PubMed]

69. Lee, S.H.R.; Qian, M.; Yang, W.; Diedrich, J.D.; Raetz, E.; Yang, W.; Dong, Q.; Devidas, M.; Pei, D.; Yeoh, A.; et al. Genome-wide association study of susceptibility loci for TCF3-PBX1 acute lymphoblastic leukemia in children. J. Natl. Cancer Inst. 2020. [CrossRef]

70. Harrison, C.J. Blood Spotlight on iAMP21 acute lymphoblastic leukemia (ALL), a high-risk pediatric disease. Blood 2015, 125, 1383-1386. [CrossRef]

71. Li, Y.; Schwab, C.; Ryan, S.; Papaemmanuil, E.; Robinson, H.M.; Jacobs, P.; Moorman, A.V.; Dyer, S.; Borrow, J.; Griffiths, M.; et al. Constitutional and somatic rearrangement of chromosome 21 in acute lymphoblastic leukaemia. Nature 2014, 508, 98-102. [CrossRef]

72. Harrison, C.J.; Moorman, A.V.; Schwab, C.; Carroll, A.J.; Raetz, E.A.; Devidas, M.; Strehl, S.; Nebral, K.; Harbott, J.; Teigler-Schlegel, A.; et al. An international study of intrachromosomal amplification of chromosome 21 (iAMP21): Cytogenetic characterization and outcome. Leukemia 2014, 28, 1015-1021. [CrossRef] [PubMed]

73. Sinclair, P.B.; Ryan, S.; Bashton, M.; Hollern, S.; Hanna, R.; Case, M.; Schwalbe, E.C.; Schwab, C.J.; Cranston, R.E.; Young, B.D.; et al. SH2B3 inactivation through $\mathrm{CN}-\mathrm{LOH} 12 \mathrm{q}$ is uniquely associated with B-cell precursor ALL with iAMP21 or other chromosome 21 gain. Leukemia 2019, 33, 1881-1894. [CrossRef]

74. Heerema, N.A.; Carroll, A.J.; Devidas, M.; Loh, M.L.; Borowitz, M.J.; Gastier-Foster, J.M.; Larsen, E.C.; Mattano, L.A., Jr.; Maloney, K.W.; Willman, C.L.; et al. Intrachromosomal amplification of chromosome 21 is associated with inferior outcomes in children with acute lymphoblastic leukemia treated in contemporary standard-risk Children's Oncology Group studies: A report from the Children's Oncology Group. J. Clin. Oncol. 2013, 31, 3397-3402. [CrossRef] [PubMed]

75. Moorman, A.V.; Robinson, H.; Schwab, C.; Richards, S.M.; Hancock, J.; Mitchell, C.D.; Goulden, N.; Vora, A.; Harrison, C.J. Risk-directed treatment intensification significantly reduces the risk of relapse among children and adolescents with acute lymphoblastic leukemia and intrachromosomal amplification of chromosome 21: A comparison of the MRC ALL97/99 and UKALL2003 trials. J. Clin. Oncol. 2013, 31, 3389-3396. [CrossRef] [PubMed]

76. Cobaleda, C.; Schebesta, A.; Delogu, A.; Busslinger, M. Pax5: The guardian of B cell identity and function. Nat. Immunol. 2007, 8, 463-470. [CrossRef] [PubMed]

77. Mullighan, C.G.; Goorha, S.; Radtke, I.; Miller, C.B.; Coustan-Smith, E.; Dalton, J.D.; Girtman, K.; Mathew, S.; Ma, J.; Pounds, S.B.; et al. Genome-wide analysis of genetic alterations in acute lymphoblastic leukaemia. Nature 2007, 446, 758-764. [CrossRef]

78. Hirabayashi, S.; Butler, E.R.; Ohki, K.; Kiyokawa, N.; Bergmann, A.K.; Möricke, A.; Boer, J.M.; Cavé, H.; Cazzaniga, G.; Yeoh, A.E.J.; et al. Clinical characteristics and outcomes of B-ALL with ZNF384 rearrangements: A retrospective analysis by the Ponte di Legno Childhood ALL Working Group. Leukemia 2021. [CrossRef]

79. Alexander, T.B.; Gu, Z.; Iacobucci, I.; Dickerson, K.; Choi, J.K.; Xu, B.; Payne-Turner, D.; Yoshihara, H.; Loh, M.L.; Horan, J.; et al. The genetic basis and cell of origin of mixed phenotype acute leukaemia. Nature 2018, 562, 373-379. [CrossRef] 
80. Hirabayashi, S.; Ohki, K.; Nakabayashi, K.; Ichikawa, H.; Momozawa, Y.; Okamura, K.; Yaguchi, A.; Terada, K.; Saito, Y.; Yoshimi, A.; et al. ZNF384-related fusion genes define a subgroup of childhood B-cell precursor acute lymphoblastic leukemia with a characteristic immunotype. Haematologica 2017, 102, 118-129. [CrossRef]

81. Bueno, C.; Tejedor, J.R.; Bashford-Rogers, R.; González-Silva, L.; Valdés-Mas, R.; Agraz-Doblás, A.; Díaz de la Guardia, R.; Ribera, J.; Zamora, L.; Bilhou-Nabera, C.; et al. Natural history and cell of origin of TCF3-ZNF384 and PTPN11 mutations in monozygotic twins with concordant BCP-ALL. Blood 2019, 134, 900-905. [CrossRef]

82. Boer, J.; Valsecchi, M.; Hormann, F.; Antic, Z.; Zaliova, M.; Schwab, C.; Cazzaniga, G.; Arfeuille, C.; Cavé, H.; Attarbaschi, A.; et al. NUTM1-rearranged infant and pediatric B cell precursor acute lymphoblastic leukemia: A good prognostic subtype identified in a collaborative international study. Blood 2020, 136, 25-26. [CrossRef]

83. Hormann, F.M.; Hoogkamer, A.Q.; Beverloo, H.B.; Boeree, A.; Dingjan, I.; Wattel, M.M.; Stam, R.W.; Escherich, G.; Pieters, R.; den Boer, M.L.; et al. NUTM1 is a recurrent fusion gene partner in B-cell precursor acute lymphoblastic leukemia associated with increased expression of genes on chromosome band 10p12.31-12.2. Haematologica 2019, 104, e455-e459. [CrossRef] [PubMed]

84. Cordo, V.; van der Zwet, J.; Canté-Barrett, K.; Pieters, R.; Meijerink, J. T-cell acute lymphoblastic leukemia: A roadmap to targeted therapies. Blood Cancer Discov. 2021, 2, 19-31. [CrossRef]

85. Van Vlierberghe, P.; Palomero, T.; Khiabanian, H.; van der Meulen, J.; Castillo, M.; van Roy, N.; de Moerloose, B.; Philippé, J.; González-García, S.; Toribio, M.L.; et al. PHF6 mutations in T-cell acute lymphoblastic leukemia. Nat. Genet. 2010, 42, 338-342. [CrossRef]

86. Liu, Y.; Easton, J.; Shao, Y.; Maciaszek, J.; Wang, Z.; Wilkinson, M.R.; McCastlain, K.; Edmonson, M.; Pounds, S.B.; Shi, L.; et al. The genomic landscape of pediatric and young adult T-lineage acute lymphoblastic leukemia. Nat. Genet. 2017, 49, 1211-1218. [CrossRef]

87. Schrappe, M.; Valsecchi, M.G.; Bartram, C.R.; Schrauder, A.; Panzer-Grümayer, R.; Möricke, A.; Parasole, R.; Zimmermann, M.; Dworzak, M.; Buldini, B.; et al. Late MRD response determines relapse risk overall and in subsets of childhood T-cell ALL: Results of the AIEOP-BFM-ALL 2000 study. Blood 2011, 118, 2077-2084. [CrossRef]

88. Salzer, W.L.; Burke, M.J.; Devidas, M.; Dai, Y.; Hardy, K.K.; Kairalla, J.A.; Gore, L.; Hilden, J.M.; Larsen, E.; Rabin, K.R.; et al. Impact of intrathecal triple therapy versus intrathecal methotrexate on disease-free survival for high-risk B-lymphoblastic leukemia: Children's Oncology Group Study AALL1131. J. Clin. Oncol. 2020, 38, 2628-2638. [CrossRef]

89. Teachey, D.T.; Devidas, M.; Wood, B.L.; Chen, Z.; Hayashi, R.J.; Annett, R.D.; Asselin, B.L.; August, K.J.; Cho, S.Y.; Dunsmore, K.P.; et al. Cranial radiation can be eliminated in most children with T-cell acute lymphoblastic leukemia (T-ALL) and bortezomib potentially improves survival in children with T-cell lymphoblastic lymphoma (T-LL): Results of Children's Oncology Group (COG) trial AALL1231. Blood 2020, 136, 11-12. [CrossRef]

90. Coustan-Smith, E.; Mullighan, C.G.; Onciu, M.; Behm, F.G.; Raimondi, S.C.; Pei, D.; Cheng, C.; Su, X.; Rubnitz, J.E.; Basso, G.; et al. Early T-cell precursor leukaemia: A subtype of very high-risk acute lymphoblastic leukaemia. Lancet Oncol. 2009, 10, 147-156. [CrossRef]

91. Zhang, J.; Ding, L.; Holmfeldt, L.; Wu, G.; Heatley, S.L.; Payne-Turner, D.; Easton, J.; Chen, X.; Wang, J.; Rusch, M.; et al. The genetic basis of early T-cell precursor acute lymphoblastic leukaemia. Nature 2012, 481, 157-163. [CrossRef]

92. Conter, V.; Valsecchi, M.G.; Buldini, B.; Parasole, R.; Locatelli, F.; Colombini, A.; Rizzari, C.; Putti, M.C.; Barisone, E.; Lo Nigro, L.; et al. Early T-cell precursor acute lymphoblastic leukaemia in children treated in AIEOP centres with AIEOP-BFM protocols: A retrospective analysis. Lancet Haematol. 2016, 3, e80-e86. [CrossRef]

93. Raetz, E.A.; Teachey, D.T. T-cell acute lymphoblastic leukemia. Hematol. Am. Soc. Hematol. Educ. Program. 2016, 2016, 580-588. [CrossRef] [PubMed]

94. Jain, N.; Lamb, A.V.; O’Brien, S.; Ravandi, F.; Konopleva, M.; Jabbour, E.; Zuo, Z.; Jorgensen, J.; Lin, P.; Pierce, S.; et al. Early T-cell precursor acute lymphoblastic leukemia/lymphoma (ETP-ALL/LBL) in adolescents and adults: A high-risk subtype. Blood 2016, 127, 1863-1869. [CrossRef]

95. Patrick, K.; Wade, R.; Goulden, N.; Mitchell, C.; Moorman, A.V.; Rowntree, C.; Jenkinson, S.; Hough, R.; Vora, A. Outcome for children and young people with Early T-cell precursor acute lymphoblastic leukaemia treated on a contemporary protocol, UKALL 2003. Br. J. Haematol. 2014, 166, 421-424. [CrossRef]

96. Richard-Carpentier, G.; Jabbour, E.; Short, N.J.; Rausch, C.R.; Savoy, J.M.; Bose, P.; Yilmaz, M.; Jain, N.; Borthakur, G.; Ohanian, M.; et al. Clinical experience with venetoclax combined with chemotherapy for relapsed or refractory T-cell acute lymphoblastic leukemia. Clin. Lymphoma Myeloma Leuk. 2020, 20, 212-218. [CrossRef] [PubMed]

97. Campana, D.; Pui, C.H. Minimal residual disease-guided therapy in childhood acute lymphoblastic leukemia. Blood 2017, 129, 1913-1918. [CrossRef] [PubMed]

98. Van Dongen, J.J.; van der Velden, V.H.; Bruggemann, M.; Orfao, A. Minimal residual disease diagnostics in acute lymphoblastic leukemia: Need for sensitive, fast, and standardized technologies. Blood 2015, 125, 3996-4009. [CrossRef]

99. Della Starza, I.; Chiaretti, S.; de Propris, M.S.; Elia, L.; Cavalli, M.; de Novi, L.A.; Soscia, R.; Messina, M.; Vitale, A.; Guarini, A.; et al. Minimal residual disease in acute lymphoblastic leukemia: Technical and clinical advances. Front. Oncol. $2019,9,726$. [CrossRef]

100. Faham, M.; Zheng, J.; Moorhead, M.; Carlton, V.E.; Stow, P.; Coustan-Smith, E.; Pui, C.H.; Campana, D. Deep-sequencing approach for minimal residual disease detection in acute lymphoblastic leukemia. Blood 2012, 120, 5173-5180. [CrossRef] [PubMed] 
101. Wu, D.; Emerson, R.O.; Sherwood, A.; Loh, M.L.; Angiolillo, A.; Howie, B.; Vogt, J.; Rieder, M.; Kirsch, I.; Carlson, C.; et al. Detection of minimal residual disease in B lymphoblastic leukemia by high-throughput sequencing of IGH. Clin. Cancer Res. 2014, 20, 4540-4548. [CrossRef] [PubMed]

102. Wood, B.; Wu, D.; Crossley, B.; Dai, Y.; Williamson, D.; Gawad, C.; Borowitz, M.J.; Devidas, M.; Maloney, K.W.; Larsen, E.; et al. Measurable residual disease detection by high-throughput sequencing improves risk stratification for pediatric B-ALL. Blood 2018, 131, 1350-1359. [CrossRef] [PubMed]

103. Pulsipher, M.A.; Carlson, C.; Langholz, B.; Wall, D.A.; Schultz, K.R.; Bunin, N.; Kirsch, I.; Gastier-Foster, J.M.; Borowitz, M.; Desmarais, C.; et al. IgH-V(D)J NGS-MRD measurement pre- and early post-allotransplant defines very low- and very high-risk ALL patients. Blood 2015, 125, 3501-3508. [CrossRef] [PubMed]

104. Hay, K.A.; Gauthier, J.; Hirayama, A.V.; Voutsinas, J.M.; Wu, Q.; Li, D.; Gooley, T.A.; Cherian, S.; Chen, X.; Pender, B.S.; et al. Factors associated with durable EFS in adult B-cell ALL patients achieving MRD-negative CR after CD19 CAR T-cell therapy. Blood 2019, 133, 1652-1663. [CrossRef]

105. Enshaei, A.; O'Connor, D.; Bartram, J.; Hancock, J.; Harrison, C.J.; Hough, R.; Samarasinghe, S.; den Boer, M.L.; Boer, J.M.; de Groot-Kruseman, H.A.; et al. A validated novel continuous prognostic index to deliver stratified medicine in pediatric acute lymphoblastic leukemia. Blood 2020, 135, 1438-1446. [CrossRef] [PubMed]

106. Gocho, Y.; Liu, J.; Hu, J.; Yang, W.; Dharia, N.V.; Zhang, J.; Shi, H.; Du, G.; John, A.; Lin, T.-N.; et al. Network-based systems pharmacology reveals heterogeneity in LCK and BCL2 signaling and therapeutic sensitivity of T-cell acute lymphoblastic leukemia. Nat. Cancer 2021, 2, 284-299. [CrossRef]

107. Kapoor, I.; Bodo, J.; Hill, B.T.; Hsi, E.D.; Almasan, A. Targeting BCL-2 in B-cell malignancies and overcoming therapeutic resistance. Cell Death Dis. 2020, 11, 941. [CrossRef]

108. Khaw, S.L.; Suryani, S.; Evans, K.; Richmond, J.; Robbins, A.; Kurmasheva, R.T.; Billups, C.A.; Erickson, S.W.; Guo, Y.; Houghton, P.J.; et al. Venetoclax responses of pediatric ALL xenografts reveal sensitivity of MLL-rearranged leukemia. Blood 2016, 128, 1382-1395. [CrossRef]

109. Scherr, M.; Elder, A.; Battmer, K.; Barzan, D.; Bomken, S.; Ricke-Hoch, M.; Schröder, A.; Venturini, L.; Blair, H.J.; Vormoor, J.; et al. Differential expression of miR-17 92 identifies BCL2 as a therapeutic target in BCR-ABL-positive B-lineage acute lymphoblastic leukemia. Leukemia 2014, 28, 554-565. [CrossRef]

110. Peirs, S.; Matthijssens, F.; Goossens, S.; van de Walle, I.; Ruggero, K.; de Bock, C.E.; Degryse, S.; Canté-Barrett, K.; Briot, D.; Clappier, E.; et al. ABT-199 mediated inhibition of BCL-2 as a novel therapeutic strategy in T-cell acute lymphoblastic leukemia. Blood 2014, 124, 3738-3747. [CrossRef] [PubMed]

111. Chonghaile, T.N.; Roderick, J.E.; Glenfield, C.; Ryan, J.; Sallan, S.E.; Silverman, L.B.; Loh, M.L.; Hunger, S.P.; Wood, B.; DeAngelo, D.J.; et al. Maturation stage of T-cell acute lymphoblastic leukemia determines BCL-2 versus BCL-XL dependence and sensitivity to ABT-199. Cancer Discov. 2014, 4, 1074-1087. [CrossRef] [PubMed]

112. Autry, R.J.; Paugh, S.W.; Carter, R.; Shi, L.; Liu, J.; Ferguson, D.C.; Lau, C.E.; Bonten, E.J.; Yang, W.; McCorkle, J.R.; et al. Integrative genomic analyses reveal mechanisms of glucocorticoid resistance in acute lymphoblastic leukemia. Nat. Cancer 2020, 1, 329-344. [CrossRef]

113. Karol, S.E.; Cooper, T.M.; Bittencourt, H.; Gore, L.; O’Brien, M.M.; Fraser, C.; Gambart, M.; Cario, G.; Zwaan, C.M.; Bourquin, J.-P.; et al. Safety, efficacy, and PK of the BCL2 inhibitor venetoclax in combination with chemotherapy in pediatric and young adult patients with relapsed/refractory acute myeloid leukemia and acute lymphoblastic leukemia: Phase 1 study. Blood 2019, 134, 2649. [CrossRef]

114. Pullarkat, V.A.; Lacayo, N.J.; Jabbour, E.; Rubnitz, J.E.; Bajel, A.; Laetsch, T.W.; Leonard, J.; Colace, S.I.; Khaw, S.L.; Fleming, S.A.; et al. Venetoclax and navitoclax in combination with chemotherapy in patients with relapsed or refractory acute lymphoblastic leukemia and lymphoblastic lymphoma. Cancer Discov. 2021. [CrossRef]

115. Horton, T.M.; Gannavarapu, A.; Blaney, S.M.; D'Argenio, D.Z.; Plon, S.E.; Berg, S.L. Bortezomib interactions with chemotherapy agents in acute leukemia in vitro. Cancer Chemother. Pharmacol. 2006, 58, 13-23. [CrossRef] [PubMed]

116. Messinger, Y.H.; Gaynon, P.S.; Sposto, R.; van der Giessen, J.; Eckroth, E.; Malvar, J.; Bostrom, B.C.; Therapeutic Advances in Childhood Leukemia \& Lymphoma (TACL) Consortium. Bortezomib with chemotherapy is highly active in advanced B-precursor acute lymphoblastic leukemia: Therapeutic Advances in Childhood Leukemia \& Lymphoma (TACL) Study. Blood 2012, 120, 285-290. [CrossRef] [PubMed]

117. Gutierrez, A.; Sanda, T.; Grebliunaite, R.; Carracedo, A.; Salmena, L.; Ahn, Y.; Dahlberg, S.; Neuberg, D.; Moreau, L.A.; Winter, S.S.; et al. High frequency of PTEN, PI3K, and AKT abnormalities in T-cell acute lymphoblastic leukemia. Blood 2009, 114, 647-650. [CrossRef] [PubMed]

118. Teachey, D.T.; Obzut, D.A.; Cooperman, J.; Fang, J.; Carroll, M.; Choi, J.K.; Houghton, P.J.; Brown, V.I.; Grupp, S.A. The mTOR inhibitor CCI-779 induces apoptosis and inhibits growth in preclinical models of primary adult human ALL. Blood 2006, 107, 1149-1155. [CrossRef]

119. Wei, G.; Twomey, D.; Lamb, J.; Schlis, K.; Agarwal, J.; Stam, R.W.; Opferman, J.T.; Sallan, S.E.; den Boer, M.L.; Pieters, R.; et al. Gene expression-based chemical genomics identifies rapamycin as a modulator of MCL1 and glucocorticoid resistance. Cancer Cell 2006, 10, 331-342. [CrossRef] [PubMed]

120. Crazzolara, R.; Cisterne, A.; Thien, M.; Hewson, J.; Baraz, R.; Bradstock, K.F.; Bendall, L.J. Potentiating effects of RAD001 (Everolimus) on vincristine therapy in childhood acute lymphoblastic leukemia. Blood 2009, 113, 3297-3306. [CrossRef] [PubMed] 
121. Avellino, R.; Romano, S.; Parasole, R.; Bisogni, R.; Lamberti, A.; Poggi, V.; Venuta, S.; Romano, M.F. Rapamycin stimulates apoptosis of childhood acute lymphoblastic leukemia cells. Blood 2005, 106, 1400-1406. [CrossRef]

122. Place, A.E.; Pikman, Y.; Stevenson, K.E.; Harris, M.H.; Pauly, M.; Sulis, M.L.; Hijiya, N.; Gore, L.; Cooper, T.M.; Loh, M.L.; et al. Phase I trial of the mTOR inhibitor everolimus in combination with multi-agent chemotherapy in relapsed childhood acute lymphoblastic leukemia. Pediatr. Blood Cancer 2018, 65, e27062. [CrossRef] [PubMed]

123. Sandoval, J.; Esteller, M. Cancer epigenomics: Beyond genomics. Curr. Opin. Genet. Dev. 2012, 22, 50-55. [CrossRef] [PubMed]

124. Garcia-Manero, G.; Bueso-Ramos, C.; Daniel, J.; Williamson, J.; Kantarjian, H.M.; Issa, J.P. DNA methylation patterns at relapse in adult acute lymphocytic leukemia. Clin. Cancer Res. 2002, 8, 1897-1903. [PubMed]

125. Burke, M.J.; Kostadinov, R.; Sposto, R.; Gore, L.; Kelley, S.M.; Rabik, C.; Trepel, J.B.; Lee, M.J.; Yuno, A.; Lee, S.; et al. Decitabine and Vorinostat with Chemotherapy in Relapsed Pediatric Acute Lymphoblastic Leukemia: A TACL Pilot Study. Clin. Cancer Res. 2020, 26, 2297-2307. [CrossRef]

126. Inaba, H.; Pui, C.H. Immunotherapy in pediatric acute lymphoblastic leukemia. Cancer Metastasis Rev. 2019, 38, 595-610. [CrossRef]

127. Kantarjian, H.; Stein, A.; Gökbuget, N.; Fielding, A.K.; Schuh, A.C.; Ribera, J.M.; Wei, A.; Dombret, H.; Foà, R.; Bassan, R.; et al. Blinatumomab versus chemotherapy for advanced acute lymphoblastic leukemia. N. Engl. J. Med. 2017, 376, 836-847. [CrossRef]

128. Gökbuget, N.; Dombret, H.; Bonifacio, M.; Reichle, A.; Graux, C.; Faul, C.; Diedrich, H.; Topp, M.S.; Bruggemann, M.; Horst, H.A.; et al. Blinatumomab for minimal residual disease in adults with B-cell precursor acute lymphoblastic leukemia. Blood 2018, 131, 1522-1531. [CrossRef]

129. Brown, P.A.; Ji, L.; Xu, X.; Devidas, M.; Hogan, L.E.; Borowitz, M.J.; Raetz, E.A.; Zugmaier, G.; Sharon, E.; Bernhardt, M.B.; et al. Effect of postreinduction therapy consolidation with blinatumomab vs. chemotherapy on disease-free survival in children, adolescents, and young adults with first relapse of B-cell acute lymphoblastic leukemia: A randomized clinical trial. JAMA 2021, 325, 833-842. [CrossRef]

130. Locatelli, F.; Zugmaier, G.; Rizzari, C.; Morris, J.D.; Gruhn, B.; Klingebiel, T.; Parasole, R.; Linderkamp, C.; Flotho, C.; Petit, A.; et al. Effect of blinatumomab vs. chemotherapy on event-free survival among children with high-risk first-relapse B-cell acute lymphoblastic leukemia: A randomized clinical trial. JAMA 2021, 325, 843-854. [CrossRef]

131. Orlando, E.J.; Han, X.; Tribouley, C.; Wood, P.A.; Leary, R.J.; Riester, M.; Levine, J.E.; Qayed, M.; Grupp, S.A.; Boyer, M.; et al. Genetic mechanisms of target antigen loss in CAR19 therapy of acute lymphoblastic leukemia. Nat. Med. 2018, 24, 1504-1506. [CrossRef]

132. Sotillo, E.; Barrett, D.M.; Black, K.L.; Bagashev, A.; Oldridge, D.; Wu, G.; Sussman, R.; Lanauze, C.; Ruella, M.; Gazzara, M.R.; et al. Convergence of acquired mutations and alternative splicing of CD19 enables resistance to CART-19 immunotherapy. Cancer Discov. 2015, 5, 1282-1295. [CrossRef] [PubMed]

133. Jacoby, E.; Nguyen, S.M.; Fountaine, T.J.; Welp, K.; Gryder, B.; Qin, H.; Yang, Y.; Chien, C.D.; Seif, A.E.; Lei, H.; et al. CD19 CAR immune pressure induces B-precursor acute lymphoblastic leukaemia lineage switch exposing inherent leukaemic plasticity. Nat. Commun. 2016, 7, 12320. [CrossRef] [PubMed]

134. Oberley, M.J.; Gaynon, P.S.; Bhojwani, D.; Pulsipher, M.A.; Gardner, R.A.; Hiemenz, M.C.; Ji, J.; Han, J.; O'Gorman, M.R.G.; Wayne, A.S.; et al. Myeloid lineage switch following chimeric antigen receptor T-cell therapy in a patient with TCF3-ZNF384 fusion-positive B-lymphoblastic leukemia. Pediatr. Blood Cancer 2018, 65, e27265. [CrossRef] [PubMed]

135. Braig, F.; Brandt, A.; Goebeler, M.; Tony, H.P.; Kurze, A.K.; Nollau, P.; Bumm, T.; Bottcher, S.; Bargou, R.C.; Binder, M. Resistance to anti-CD19/CD3 BiTE in acute lymphoblastic leukemia may be mediated by disrupted CD19 membrane trafficking. Blood 2017, 129, 100-104. [CrossRef]

136. Maude, S.L.; Teachey, D.T.; Porter, D.L.; Grupp, S.A. CD19-targeted chimeric antigen receptor T-cell therapy for acute lymphoblastic leukemia. Blood 2015, 125, 4017-4023. [CrossRef] [PubMed]

137. Maude, S.L.; Laetsch, T.W.; Buechner, J.; Rives, S.; Boyer, M.; Bittencourt, H.; Bader, P.; Verneris, M.R.; Stefanski, H.E.; Myers, G.D.; et al. Tisagenlecleucel in children and young adults with B-cell lymphoblastic leukemia. N. Engl. J. Med. 2018, 378, 439-448. [CrossRef] [PubMed]

138. Maude, S.L.; Frey, N.; Shaw, P.A.; Aplenc, R.; Barrett, D.M.; Bunin, N.J.; Chew, A.; Gonzalez, V.E.; Zheng, Z.; Lacey, S.F.; et al. Chimeric antigen receptor T cells for sustained remissions in leukemia. N. Engl. J. Med. 2014, 371, 1507-1517. [CrossRef]

139. Kadauke, S.; Myers, R.M.; Li, Y.; Aplenc, R.; Baniewicz, D.; Barrett, D.M.; Barz Leahy, A.; Callahan, C.; Dolan, J.G.; Fitzgerald, J.C.; et al. Risk-adapted preemptive tocilizumab to prevent severe cytokine release syndrome after CTL019 for pediatric B-cell acute lymphoblastic leukemia: A prospective clinical trial. J. Clin. Oncol. 2021, 39, 920-930. [CrossRef]

140. Hill, J.A.; Seo, S.K. How I prevent infections in patients receiving CD19-targeted chimeric antigen receptor T cells for B-cell malignancies. Blood 2020, 136, 925-935. [CrossRef]

141. Shah, N.N.; Fry, T.J. Mechanisms of resistance to CAR T cell therapy. Nat. Rev. Clin. Oncol. 2019, 16, 372-385. [CrossRef]

142. Majzner, R.G.; Mackall, C.L. Tumor antigen escape from CAR T-cell therapy. Cancer Discov. 2018, 8, 1219-1226. [CrossRef]

143. Fry, T.J.; Shah, N.N.; Orentas, R.J.; Stetler-Stevenson, M.; Yuan, C.M.; Ramakrishna, S.; Wolters, P.; Martin, S.; Delbrook, C.; Yates, B.; et al. CD22-targeted CAR T cells induce remission in B-ALL that is naive or resistant to CD19-targeted CAR immunotherapy. Nat. Med. 2018, 24, 20-28. [CrossRef] [PubMed] 
144. Qin, H.; Cho, M.; Haso, W.; Zhang, L.; Tasian, S.K.; Oo, H.Z.; Negri, G.L.; Lin, Y.; Zou, J.; Mallon, B.S.; et al. Eradication of B-ALL using chimeric antigen receptor-expressing T cells targeting the TSLPR oncoprotein. Blood 2015, 126, 629-639. [CrossRef] [PubMed]

145. Schultz, L.M.; Muffly, L.S.; Spiegel, J.Y.; Ramakrishna, S.; Hossain, N.; Baggott, C.; Sahaf, B.; Patel, S.; Craig, J.; Yoon, J.; et al. Phase I trial using CD19/CD22 bispecific CAR T cells in pediatric and adult acute lymphoblastic leukemia (ALL). Blood 2019, 134, 744. [CrossRef]

146. Wang, N.; Hu, X.; Cao, W.; Li, C.; Xiao, Y.; Cao, Y.; Gu, C.; Zhang, S.; Chen, L.; Cheng, J.; et al. Efficacy and safety of CAR19/22 T-cell cocktail therapy in patients with refractory/relapsed B-cell malignancies. Blood 2020, 135, 17-27. [CrossRef] [PubMed]

147. Pan, J.; Zuo, S.; Deng, B.; Xu, X.; Li, C.; Zheng, Q.; Ling, Z.; Song, W.; Xu, J.; Duan, J.; et al. Sequential CD19-22 CAR T therapy induces sustained remission in children with $\mathrm{r} / \mathrm{r}$ B-ALL. Blood 2020, 135, 387-391. [CrossRef]

148. He, X.; Xiao, X.; Li, Q.; Jiang, Y.; Cao, Y.; Sun, R.; Jin, X.; Yuan, T.; Meng, J.; Ma, L.; et al. Anti-CD19 CAR-T as a feasible and safe treatment against central nervous system leukemia after intrathecal chemotherapy in adults with relapsed or refractory B-ALL. Leukemia 2019, 33, 2102-2104. [CrossRef]

149. Chen, X.; Wang, Y.; Ruan, M.; Li, J.; Zhong, M.; Li, Z.; Liu, F.; Wang, S.; Chen, Y.; Liu, L.; et al. Treatment of testicular relapse of B-cell acute lymphoblastic leukemia with CD19-specific chimeric antigen receptor T cells. Clin. Lymphoma Myeloma Leuk. 2019, 20, 366-370. [CrossRef]

150. Kantarjian, H.M.; DeAngelo, D.J.; Stelljes, M.; Martinelli, G.; Liedtke, M.; Stock, W.; Gökbuget, N.; O’Brien, S.; Wang, K.; Wang, T.; et al. Inotuzumab ozogamicin versus standard therapy for acute lymphoblastic leukemia. N. Engl. J. Med. 2016, 375, 740-753. [CrossRef]

151. Jabbour, E.; Ravandi, F.; Kebriaei, P.; Huang, X.; Short, N.J.; Thomas, D.; Sasaki, K.; Rytting, M.; Jain, N.; Konopleva, M.; et al. Salvage Chemoimmunotherapy With Inotuzumab Ozogamicin Combined with Mini-Hyper-CVD for Patients With Relapsed or Refractory Philadelphia Chromosome-Negative Acute Lymphoblastic Leukemia: A Phase 2 Clinical Trial. JAMA Oncol. 2018, 4, 230-234. [CrossRef]

152. Kebriaei, P.; Cutler, C.; de Lima, M.; Giralt, S.; Lee, S.J.; Marks, D.; Merchant, A.; Stock, W.; van Besien, K.; Stelljes, M. Management of important adverse events associated with inotuzumab ozogamicin: Expert panel review. Bone Marrow Transpl. 2018, 53, 449-456. [CrossRef] [PubMed]

153. Brivio, E.; Locatelli, F.; Lopez-Yurda, M.; Malone, A.; Díaz-de-Heredia, C.; Bielorai, B.; Rossig, C.; van der Velden, V.H.J.; Ammerlaan, A.C.; Thano, A.; et al. A Phase I study of inotuzumab ozogamicin in pediatric relapsed/refractory acute lymphoblastic leukemia (ITCC-059 study). Blood 2021, 137, 1582-1590. [CrossRef] [PubMed] 